\title{
El nuevo marco legal de los convenios a la luz de la reforma de la Administración Pública
}

\author{
Elisa Pérez de los Cobos Hernández
}

Ayudante Doctor en Derecho Administrativo

Universidad de Murcia

RESUMEN: La Ley 40/2015, de 1 de octubre, de Régimen Jurídico del Sector Público (LRJSP), forma parte de un ambicioso proyecto reformista dirigido a superar los efectos de la crisis económica que ha atravesado España. Este objetivo está presente en no pocos aspectos de la Ley, entre ellos, en el establecimiento de una normativa uniforme y más completa de los convenios, dirigida a mejorar la fiscalización del gasto público que se realiza a través de esta figura. De este modo, a través de un novedoso régimen jurídico básico de los convenios, la LRJSP eleva a rango de ley las propuestas y recomendaciones recogidas, tanto en el Dictamen del Tribunal de Cuentas núm. 878, de 30 de noviembre, como en el Informe CORA, arrojando luz en la práctica convencional administrativa. Una regulación que, sin perjuicio de precisar mayor detalle en algunos aspectos, ha recibido una valoración positiva.

ABSTRAC: The Law 40/2015, of 1 October, on the Legal Regime of the Public Sector is integrated in a reform project that aims at overcoming the effects of the economic crisis that has suffered from Spain. This target is present in many aspects of the law, among them, in the creation of a uniform and complete regulatory regime of the administrative agreements, with the aim of improving the control of public spending. In this way, through the new normative regulation of the conventions, the LRJSP becomes law proposals and recommendations contained in the Opinion of the Court of Auditors No. 878, 30 November and in the Report CORA, resolving the doubts practices. A normative regulation that has been judged positively, although some of the details should be improved.

Palabras clave: convenio administrativo; reforma administrativa; cooperación.

KEYWORDS: Administrative agreement; administrative reform; cooperation. 
Sumario: I. LA REFORMA DE LA ADMINISTRAGIÓN PÚBLICA EN EL NUEVO MARCO SOCIO-ECONÓMICO DE ESPAÑA. II. LA NEGESIDAD DE ESTABLECER UN ADEGUADO MARGO LEGAL PARA EL EMPLEO DEL CONVENIO DE COLABORACIÓN POR LAS ADMINISTRAGIONES PÚBLICAS. III. EL NUEVO RÉGIMEN JURÍDICO BÁSICO DE LOS CONVENIOS EN LA LEY 40/2015, DE 1 DE OCTUBRE, DE RÉGIMEN JURÍDICO DEL SECTOR PÚBLICO. 1. Concepto de convenio. A. El obligado concepto residual de los convenios de colaboración a la luz de la legislación contractual: la incidencia de las nuevas Directivas europeas de contratación pública. B. El nuevo concepto de convenio. 2. La nueva clasificación de los convenios. 3. Requisitos de validez y eficacia de los convenios. 4. Contenido del convenio. 5. Trámites preceptivos para la suscripción de los convenios. 6. Extinción de los convenios y sus efectos. 7. Remisión de los convenios al Tribunal de Cuentas. III. BREVE RECAPITULACIÓN FINAL. IV BIBLIOGRAFÍA

\section{LAREFORMADE LAADMINISTRACIÓN PÚBLICAENELNUEVO MARCO SOCIO-EGONÓMICO DE ESPAÑA}

La crisis económica global y el último ciclo de corrupción que ha vivido España han puesto en tela de juicio los pilares fundamentales de nuestro sistema público tradicional. Las dudas sobre su eficacia se han traducido en una pérdida de confianza de los ciudadanos en las instituciones y en una exigencia de adaptación de la Administración pública a las demandas de la sociedad del siglo xxi. Por ello, a pesar de que en España la crisis no tuvo su origen específico en el sector público, las condiciones fiscales y la búsqueda de respuestas estructurales a los problemas recurrentes de la economía española, centraron la atención sobre aquel ${ }^{1}$.

En este contexto, se puso de manifiesto la necesidad de contar con una Administración pública austera y eficiente como valor competitivo para nuestro país ${ }^{2}$. Era necesario abordar una profunda transformación de la Administración que permitiese la mejorar de su eficacia, calidad y eficiencia, adaptándose mejor a las necesidades de los ciudadanos ${ }^{3}$. Con este fin, el Consejo de Ministros acordó, el 26 de octubre de 2012, la creación de la Comisión para la Reforma de las Administraciones Públicas

\footnotetext{
Vid. Organización para la Cooperación y el Desarrollo Económico (OCDE), España: de la reforma administrativa a la mejora continua. Resumen ejecutivo, hallazgos y recomendaciones clave, Estudios de Gobernanza Pública de la OCDE, 2014, p. 3.

2 Gobierno de España, Referencia del Consejo de Ministros de 26 de octubre de 2012, Ministerio de Presidencia, Secretaria de Estado de Comunicación, Madrid, 2012, p. 7.

Cfr. Comisión para la Reforma de las Administraciones Públicas (CORA), Informe de la Reforma de las Administraciones Públicas, Gobierno de España, Madrid, 2013, p. 35.
} 
con el mandato de realizar un estudio integral dirigido a modernizar el sector público español, dotarle de una mayor eficacia, eliminar las duplicidades y simplificar los procedimientos a través de los cuales los ciudadanos y las empresas se relacionan con la Administración ${ }^{4}$. El informe resultante, elevado al Consejo de Ministros el 21 de junio de 2013, recogía 217 propuestas basadas en el convencimiento de que una economía competitiva exige una Administración pública eficiente, transparente, ágil y centrada en el servicio a los administrados ${ }^{5}$. En la misma línea, el Programa Nacional de Reformas de España para 2014 subrayaba la necesidad de impulsar medidas para racionalizar la actuación administrativa, mejorar la eficiencia en el uso de los recursos públicos y aumentar su productividad ${ }^{6}$.

De este modo, tomando como punto de partida el Informe CORA, se aborda una reforma integral de la organización y funcionamiento de las Administraciones que se articula en dos ejes fundamentales: de un lado, la ordenación de las relaciones ad extra de las Administraciones con los ciudadanos y empresas, y, de otro, la regulación ad intra del funcionamiento interno de cada Administración y de las relaciones entre ellas ${ }^{7}$. El resultado último fue la aprobación de dos textos legislativos, hoy en vigor, que conforman la cabecera del Derecho administrativo: la Ley 39/2015, de 1

$4 \quad$ La CORA se adscribe al Ministerio de Hacienda y Administraciones Públicas (MHAP) a través de la Secretaría de Estado de Administraciones Públicas. Para el logro de sus objetivos, la CORA se organizó en 4 subcomisiones: i) Duplicidades administrativas: a la que se le encomendó identificar y eliminar duplicidades y reforzar los mecanismos de cooperación; ii) Simplificación administrativa: que debía revisar las trabas burocráticas que dificultan la tramitación de los procedimientos administrativos con el fin de conseguir una mayor simplificación; iii) Gestión de servicios y medios comunes: destinada a centralizar actividades de gestión que, por ser similares o de la misma naturaleza, pudieran desempeñarse de forma unificada o coordinada, aprovechando así en mayor medida los medios públicos; iv) Administración institucional: cuya finalidad era analizar la distinta tipología de entes que la componen, revisando el marco normativo y los modelos que en él se identificasen como óptimos.

5 De las 217 propuestas recogidas en el Informe CORA, de 21 de junio de 2013, 139 afectan al Estado y a las Comunidades Autónomas (CCAA) y 78 exclusivamente a la Administración General del Estado (AGE). De estas 217 medidas, 11 tienen carácter general y horizontal para todos los ámbitos de la Administración Pública; 118 tienden a eliminar duplicidades con las CCAA y el Estado; 42 eliminan trabas, simplifican los procedimientos y facilitan el acceso de los ciudadanos a la Administración; 38 mejoran la gestión de los servicios y medios comunes; y 8 racionalizan la Administración Institucional, tanto en el plano normativo como mediante la supresión e integración de 57 entidades públicas estatales. Vid. CORA, Informe de la Reforma..., cit., p. 11

$6 \quad$ Cfr. Programa Nacional de Reformas de España, Gobierno de España, Madrid, 2014, p. 10.

La LRJSP responde al segundo de los ejes citados y, al amparo del art. 149.1.18 ${ }^{\mathrm{a}} \mathrm{CE}$, ordena y sistematiza las relaciones inter e intra administrativas. Por un lado, la Ley se encarga de la legislación básica sobre régimen jurídico administrativo aplicable a todas las Administraciones públicas, y, por otro, del régimen jurídico específico de la AGE, donde se incluye tanto la llamada Administración institucional, como la Administración periférica del Estado. Junto con lo anterior, la Ley incorpora la regulación sistemática de las relaciones internas entre las Administraciones públicas, estableciendo los principios generales de actuación y las técnicas de relación entre los distintos sujetos públicos. 
de octubre, de Procedimiento Administrativo Común de las Administraciones Públicas, (LPACAP), y la Ley 40/2015, de 1 de octubre, de Régimen Jurídico del Sector Público, (LRJSP) ${ }^{8}$.

La LRJSP forma parte de un ambicioso proyecto reformista dirigido a superar los efectos de la crisis económica que ha atravesado España ${ }^{9}$. Mediante esta nueva regulación se pretende alcanzar una mejora en la eficacia de la actuación administrativa que se traduzca, a la postre, en un más atento cumplimiento de los principios de disciplina presupuestaria y estabilidad financiera ${ }^{10}$. Este objetivo está presente en no pocos aspectos de la Ley, entre ellos, y por lo que aquí importa, en el establecimiento de una normativa uniforme y más completa de los convenios con la que mejorar la fiscalización del gasto público que se realiza a través de esta figura ${ }^{11}$.

De este modo, y dejando de lado otros debates que el nuevo régimen jurídico del sector público plantea, se acota el objeto del presente estudio al examen de las principales novedades que la LRJSP introduce en el régimen de los convenios, como instrumentos esenciales de las relaciones interadministrativas necesarias para el buen funcionamiento del Estado Autonómico.

\section{LA NEGESIDAD DE ESTABLEGER UN ADEGUADO MARCO LEGAL PARA EL EMPLEO DEL GONVENIO DE COLABORA- CIÓN POR LAS ADMINISTRACIONES PÚBLICAS}

La pormenorizada regulación de los convenios que hoy recoge la LRJSP responde a las propuestas y recomendaciones realizadas por el Tribunal de Cuentas (TCu) en su Moción a las Cortes Generales núm. 878, de 30 de noviembre de 2010, sobre la necesidad de establecer un adecuado marco legal para el empleo del conve-

\footnotetext{
Ley 39/2015, de 1 de octubre, del Procedimiento Administrativo Común de las Administraciones Públicas y Ley 40/2015, de 1 de octubre, de Régimen Jurídico del Sector Público (ambas, BOE núm. 236, de 2 de octubre de 2015).

9 En la misma línea reformista, integrando las directrices del Informe CORA, pueden identificarse otras normas como la Ley 19/2013, de 9 de diciembre, de transparencia, acceso a la información pública y buen gobierno, (BOE núm. 295, de 10 de diciembre de 2013); Ley 27/2013, de 27 de diciembre, de racionalización y sostenibilidad de la Administración Local, (BOE núm. 312, de 30 de diciembre de 2013); o la Ley 15/2014, de 16 de septiembre, de racionalización del Sector Público y otras medidas de reforma administrativa, (BOE núm. 226, de 17 de septiembre de 2014).

10 Vid. Ministerio de Hacienda y Administraciones Públicas y Ministerio de Presidencia, $M e^{-}$ moria de análisis de impacto normativo del Anteproyecto de Ley de Régimen Furídico del Sector Público, Madrid, 9 de enero 2015, pp. 6-9.

11 Dictamen del Consejo de Estado núm. 274/2015, de 29 de abril, Anteproyecto de Ley de Régimen furídico del Sector Público, apartado III "Consideraciones generales", subapartado b) "Sobre la finalidad perseguida por el anteproyecto".
} 
nio de colaboración por las Administraciones públicas ${ }^{12}$. El TGu puso de manifiesto que, a pesar del creciente empleo del convenio de colaboración, - tanto entre la Administración o entidades públicas como de éstas con los administrados - y del hecho de que a través de este instrumento se canalicen importantes cantidades de recursos públicos, esta figura carecía de una regulación sistemática en nuestro país, al menos, en el ámbito de la legislación del Estado ${ }^{13}$.

El insuficiente marco regulatorio de los convenios ha dado pie a prácticas "que soslayan la aplicación de la legislación contractual, resintiéndose, por tanto, la gestión de los fondos públicos que discurre por cauces jurídicamente inseguros, y la aplicación de los principios de legalidad, eficiencia y economía"14. Una conducta generalizada que, como señala FuerTes LóPEz, ha dado lugar a "una gran vía de agua en la legislación española hecha a golpe de convenio que han podido hundir todo el barco de previsiones legislativas que tratan de garantizar una actuación contractual pública, que garantiza la no discriminación y favorece la competencia empresarial"15. Misma conducta que ha hecho necesaria, en no pocas ocasiones, la intervención de los Tribunales para la declaración de nulidad de muchos de estos convenios ${ }^{16}$. En realidad, el problema radica en que la normativa reguladora de los convenios se ha encontrado tradicionalmente dispersa en una multiplicidad de normas poco claras. Muchas de ellas destinadas a regular aspectos parciales o modalidades concretas, y

12 BOCG núm. 480, Serie A, Ix Legislatura, de 28 de octubre de 2011.

13 En este sentido, el Informe de la Secretaría de Estado de Cooperación Territorial sobre los Convenios de colaboración Estado-CCAA suscritos durante 2009, señala que, el número de convenios suscritos en el periodo 1999-2009, ascendió a un total de 10.251, elevándose la aportación estatal por esta vía a 32.527,40 millones de euros. En el año 2012, de acuerdo con los datos que obran en el Informe CORA, los convenios en el Sector Publico estatal ascendieron a 7.100. A los anteriores, como señala el TCu, deben añadirse "los demás celebrados por la AGE con Entidades Locales y otras entidades públicas de los que no existe información estadística, ni habitualmente se publican en el BOE. También se carece de información estadística de los celebrados con entidades privadas, si bien existe evidencia de que son numerosos". Dictamen del Tribunal de Cuentas núm. 878, de 30 de noviembre de 2010, Moción a las Cortes Generales sobre la necesidad de establecer un adecuado marco legal para el empleo del convenio de colaboración por las Administraciones públicas, pp. 7-8.

14 Dictamen del TGu núm. 878, de 30 de noviembre de 2010, cit., p. 7.

15 Fuertes López, M., "Los convenios y los consorcios en la Ley del Sector Público", conferencia impartida en el Seminari de Dret Local: les lleis 39 i 40 de 2015, de Procediment Administratiu i Règim furídic del Sector Públic, Federación de Municipios de Cataluña, Barcelona, 20 de noviembre de 2015, p. 16.

16 Por todas, STS, Sala de lo Contencioso Administrativo, Secc. $7^{\text {a }}$, de 20 de marzo de 2012, por la que se desestima el recurso interpuesto por la AGE frente a la Sentencia de 30 de septiembre de 2008 de

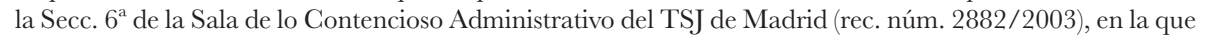
se declara la nulidad del convenio de colaboración suscrito entre la Sociedad Estatal Correos y Telégrafos S.A. y el Ministerio del Interior, de 17 de diciembre de 2002; en el mismo sentido, la STS, Sala de lo Contencioso -Administrativo, Secc. $4^{\text {a }}$, de 18 de febrero de 2004, por la que se declara la nulidad del convenio suscrito el 6 de octubre de 1995 entre el departamento de Agricultura, Ganadería y Pesca de la Generalitat de Cataluña y el Grupo de Sanidad Porcina de Lérida, al no ser conforme a derecho. 
solo algunas, las menos, a la regulación de elementos comunes ${ }^{17}$. Un foco inagotable de dudas sobre la correcta legislación aplicable que ha afectado, tanto a los gestores públicos y los órganos de control, como a los terceros con los que se formalizan los convenios.

La exhaustiva labor fiscalizadora del TCu ha permitido identificar las debilidades más relevantes de la actividad convencional de la Administración. Sin agotar el total de incidencias detectadas por el Alto Tribunal, se comprueba que la mayoría de convenios celebrados con personas sujetas a derecho privado se han suscrito sin una norma habilitante específica; sin realizar actuaciones tendentes a dar publicidad; con una escasa concreción de su objeto y de los criterios para determinar las aportaciones de la Administración pública; o encubriendo verdaderos contratos administrativos o subvenciones públicas sin atender a su legislación específica. Por lo que se refiere a los convenios celebrados entre la AGE y las Entidades Locales u otras Administraciones o entidades públicas, las incidencias detectadas son en buena parte coincidentes con las ya expuestas. Se constatan las anomalías y la falta de seguridad en los convenios que canalizan subvenciones de la AGE a favor de las CGAA; una incorrecta aplicación de los principios de publicidad, concurrencia, igualdad y no discriminación; falta de concreción de las actuaciones a realizar por las partes; y, una generalizada ausencia de previsiones en el clausulado del convenio con las que hacer frente a ulteriores incidencias en la fase de ejecución ${ }^{18}$. Partiendo de estas consideraciones, el TCu propuso un conjunto de medidas dirigidas a mejorar la gestión económico financiera del sector público, instándose al Gobierno a realizar las modificaciones normativas necesarias para hacerlas efectivas ${ }^{19}$.

\footnotetext{
17 Como señala el TCu, "estas normas abordan aspectos parciales o modalidades concretas, de las cuales sólo algunas, pueden considerarse comunes a los distintos tipos de convenios, mientras que otras únicamente conciernen a algunos de ellos”. Dictamen del TGu núm. 878, de 30 de noviembre de 2010, cit.,

18 Ibídem, pp. 8-14.

19 En consideración a los resultados obtenidos en su Dictamen, el TGu formula un total de dieciséis propuestas para su consideración por las Cortes Generales y su traslado al Gobierno. Entre éstas, dada su importancia, destacan las siguientes: " 1 a) que se complete y sistematice el marco legal de estos convenios de colaboración, que se formule un concepto diferenciándolo de figuras afines, que se precisen sus ámbitos subjetivo y objetivo, y los extremos que puede comprender su contenido; $2^{\mathrm{a}}$ ) que se precise el marco jurídico aplicable a los convenios que se celebren por entidades públicas regidas por el derecho privado con otras entidades o Administraciones públicas; $3^{\text {a }}$ ) que se precise en qué medida las relaciones entre la Administración centralizada y los organismos públicos vinculados o dependientes de aquella pueden canalizarse mediante convenios de colaboración, o si debe producirse mediante encomiendas de gestión; $15^{\mathrm{a}}$ ) que se complete y amplíe la información sobre los convenios mediante un sistema registral; $16^{\mathrm{a}}$ ) que la obligación de remitir al TCu información sobre los contratos celebrados por las entidades del sector público que se regula en el art. 29 LCSP y en los arts. 39 y 40 de la LFTCu, se haga extensiva con las necesarias adaptaciones a los convenios de colaboración". Vid. Dictamen del TGu núm. 878, de 30 de noviembre de 2010, cit., pp. 3234. A la vista de lo anterior, la Comisión Mixta para las Relaciones con el TCu, en su sesión del día 18 de
} p. 15 . 
Pero no solo el TCu advierte de las deficiencias en la regulación positiva de los convenios de colaboración, también lo hace el Informe CORA. Tras señalar la notable dispersión de entidades con competencia para firmar convenios en cada Ministerio, - reflejo de la atomización existente en la actualidad en el sector público estatal- y la reiterada utilización de la denominación «convenio de colaboración» para dar cobijo a realidades jurídicas dispares, la subcomisión de gestión de servicio y medios comunes de la CORA propuso una serie de medidas a adoptar en una línea similar a las efectuadas por el $\mathrm{TCu}^{20}$.

Así pues, las recomendaciones contempladas tanto en el Dictamen del TCu núm. 878, de 30 de noviembre de 2010, como en el Informe CORA, de 21 de junio de 2013, constituyen el germen del marco jurídico básico, sustantivo y de procedimiento, de los convenios que se recoge en la LRJSP y con el que se pretende dar respuesta a las dudas y prácticas irregulares que han caracterizado el uso común de los convenios de colaboración.

\section{EL NUEVO RÉGIMEN JURÍDICO BÁSICO DE LOS CONVE- NIOS EN LA LEY 40/2015, DE 1 DE OCTUBRE, DE RÉGIMEN JURÍDICO DEL SECTOR PÚBLICO}

La LRJSP desarrolla en el Capítulo vi del Título preliminar, arts. 47 a 53 y Disposición adicional $8^{\mathrm{a}}$, un completo régimen jurídico básico de los convenios aplicable a todas las Administraciones públicas ex art. 149.1.18 ${ }^{a}$ CE. Para su más correcto examen, se sigue a continuación el orden establecido en la Ley, analizando detenidamente aquellos aspectos que dan cabida a las recomendaciones y propuestas del TCu y del Informe CORA.

\footnotetext{
diciembre de 2012, acordó instar al Gobierno para que, dentro de sus competencias, adoptase las medidas necesarias para la efectividad de las propuestas del Alto Tribunal. Vid. Resolución de 18 de diciembre de 2012, aprobada por la Comisión Mixta para las Relaciones con el TCu en relación con la Moción sobre la necesidad de establecer un adecuado Marco Legal para el empleo del Convenio de Colaboración por las Administraciones Públicas, (BOE núm. 64, de 15 de marzo de 2013).

${ }_{20}$ Entre las directrices recogidas en el Informe CORA pueden identificarse las siguientes: i) aprobación de una norma por la que se regule el régimen jurídico de los convenios de colaboración y su distinción de figuras análogas, así como el procedimiento para la tramitación de los mismos, en particular, si conllevan coste económico para el Sector Público estatal; ii) creación de un sistema de información de convenios de colaboración en el ámbito del Sector Público estatal con el que cumplir las obligaciones en materia de transparencia; iii) elaboración anual de un instrumento de planificación de convenios de colaboración; iv) remisión de información al TCu de los convenios coincidencia económica superior a un determinado umbral. Cfr. CORA, Informe de la Reforma..., cit., pp. 192-193.
} 


\section{Concepto de convenio}

A. El obligado concepto residual de los convenios de colaboración a la luz de la legislación contractual: la incidencia de las nuevas Directivas europeas de contratación pública

Uno de los principales estigmas de los convenios se encuentra en la falta de un adecuado concepto legal, jurisprudencial o doctrinal de esta figura. Como señala Rodríguez de Santiago, "el término convenio es utilizado, frecuentemente, como un concepto meramente descriptivo, sin pretender remitir a una precisa naturaleza jurídica de la figura a la que se refiere, sino sólo expresar que, en la formación de dicho acto jurídico, intervienen voluntades concurrentes de dos o más sujetos" ${ }^{21}$. La consecuencia directa ha sido que, tanto en las relaciones entre Administración y administrado, como en las que se entablan entre Administraciones públicas, el empleo del nomen iuris «convenio de colaboración» ha dado cobijo a una disparidad variada de realidades jurídicas.

Si bien, pese a la ausencia de un concepto legal de convenio, en el ámbito del derecho público, los negocios jurídicos bilaterales se han clasificado generalmente como contratos o convenios. Para corregir la dificultad práctica que esto planta, se recurrió a un concepto residual de convenio, derivado de una definición negativa hoy recogida en el Real Decreto Legislativo 3/2011, de 14 de noviembre, por el que se aprueba el texto refundido de la Ley de Contratos del Sector Público (TRLCSP) ${ }^{22}$. De acuerdo con esto, quedan excluidos de la aplicación del TRLCSP, tanto los convenios de colaboración interadministrativos, que por su naturaleza no tengan la consideración de contratos sujetos al TRLCSP (ex art. 4.1.c), como los convenios con personas físicas o jurídicas sujetas a derecho privado, siempre y cuando su objeto no esté comprendido en el de los contratos regulados en el TRLCSP o en normas administrativas especiales, (ex art. 4.1.d). Esta regulación negativa de la figura de los convenios se completa, además, con el apartado 2 del citado art. 4 TRLCSP, en virtud del cual, los contratos, negocios y relaciones jurídicas enumerados, entre los que figuran los convenios, se regularán por sus normas especiales, aplicándose los principios de esta Ley para resolver las dudas y lagunas que pudieran presentarse. 
Ahora bien, la redacción de estos preceptos no está exenta de dudas interpretativas en orden al alcance de dicha exclusión ${ }^{23}$. La doctrina mayoritaria ha entendido que, pese a su diferente redacción, los apartados c) y d) del art. 4 TRLCSP albergan, en realidad, un criterio idéntico, de forma que el elemento determinante de la naturaleza contractual o convencional del negocio jurídico es su objeto ${ }^{24}$. En consecuencia, como señala Santiago Iglesias, "en aquellos supuestos en los que el objeto del negocio jurídico celebrado entre las citadas entidades coincida con el de alguno de los contratos regulados en el TRLCSP no será posible el recurso a la fórmula convencional" 25 . En esta línea parece ir el TCu cuando afirma que, "siempre que el objeto del supuesto convenio coincida con el de un contrato, las condiciones subjetivas de la otra parte no lo sitúan fuera del ámbito de la contratación" ${ }^{26}$. Si bien, el Alto Tribunal añade que, "sólo una actuación conjunta de los sujetos intervinientes para la consecución del objeto, ajena a la idea de intercambio patrimonial, podría

23 Sobre el alcance de la exclusión contenida en el art. 4.1.c y d) TRLCSP, vid., Santiago Iglesias, D., "Los convenios interadministrativos", en Yzouierdo Tolsada, M. (Dir.), Tratado de Contratos, tomo XIV, Aranzadi, Cizur Menor, 2014, pp. 905 y ss; en el mismo sentido, Pascual García, J., Convenios de colaboración entre Administraciones públicas y Convenios con administrados, BOE, Madrid, 2012.

24 Pese a tratarse del criterio doctrinal mayoritario, SANTIAgo IgLesias advierte de la posibilidad de realizar una interpretación distinta del alcance del art. 4.1 c) TRLCSP, que explicaría la diferente redacción dada por el legislador a los apartados c) y d) del citado precepto. De este modo, señala la autora que, "no sería el objeto sino la causa el elemento determinante de la naturaleza convencional o contractual de un negocio jurídico. Así, en el caso de los contratos, la causa es remuneratoria: facio ut des, es decir, en los contratos interadministrativos lo determinante es la existencia de ánimo lucrativo, de tal manera que, en ellos, se realiza una actividad a cambio de la obtención de un beneficio, mientras que, en el caso de los convenios interadministrativos, la causa es la colaboración en el logro de un objetivo común a las partes que reviste interés público, facio ut facias. Así, de acuerdo con esta interpretación, quedarían excluidos del ámbito de aplicación del TRLCSP aquellos convenios interadministrativos que las Administraciones públicas intervinientes celebrasen con la finalidad de coordinar, cooperar o auxiliarse en la planificación o ejecución de las actuaciones que pretenden desarrollar, es decir, cuando persigan un objetivo común de interés público, con independencia de si su objeto coincide o no con el de alguno de los contratos regulados en dicha norma". Santiago Iglesias, D., "Las relaciones de colaboración entre poderes adjudicadores excluidas de la normativa de contratación del sector público una propuesta de transposición de la regulación contenida en las Directivas de contratación al ordenamiento español", Revista General de Derecho Administrativo, núm. 38, 2015, pp. 13-14.

25 Santiago Iglesias, D., "Las relaciones de colaboración ...”, cit., p. 12; en el mismo sentido, MeLLAdo Ruiz, L., "Ámbito subjetivo y objetivo de la aplicación de la Ley de Contratos del Sector Público", RAAP, núm. 74, 2009, p. 135.

${ }_{26}$ Entendemos que el TCu subraya la irrelevancia de las condiciones subjetivas de las partes del convenio refiriéndose a los convenios de colaboración entre Administraciones y otras entidades de derecho público, a través de los cuales se han encubierto verdaderos contratos. Así, la STJUE de 13 de enero de 2005, Asunto C-84/03, por la que se condenó al Reino de España, por excluir de forma absoluta del ámbito de aplicación de la Ley de Contratos, los convenios que se celebren entre Administraciones y otras entidades de derecho público, aun cuando por su objeto constituyan contratos públicos a los efectos de las Directivas. 
calificarse de convenio de colaboración" ${ }^{27}$. De lo anterior puede deducirse que, el criterio diferenciador entre convenio y contrato no puede quedar limitado al objeto material del negocio jurídico, debiendo tenerse en cuenta la causa del convenio. Así, mientras que en los contratos la causa es remuneratoria, en los convenios ésta reside en el logro de un objetivo común que, revistiendo interés público, no genera lucro para las partes ${ }^{2}$. Por lo tanto, de acuerdo con lo establecido en el art. 4 TRLSP, no existe posibilidad de acudir a la figura de convenio en los casos de relaciones de carácter y contenido contractual, es decir, cuando existen intereses de carácter patrimonial entre las partes que lo suscriben, con independencia de la personificación pública o privada del sujeto ${ }^{29}$.

En todo caso, debe tenerse en cuenta aquí la necesaria transposición a nuestro ordenamiento jurídico de las Directivas del Parlamento Europeo y del Consejo, 2014/23/UE, de 26 de febrero de 2014, relativa a la adjudicación de contratos de concesión y 2014/24/UE de 26 de febrero de 2014, sobre contratación pública ${ }^{30}$. Estas constituyen la culminación de un proceso de adaptación de la normativa de contratación pública iniciado en el seno de la UE en el año 2010. Sin embargo, pese al plazo máximo concedido para su transposición, vencido en 2016, el Proyecto de Ley de Contratos del Sector Público, por el se transponen al ordenamiento jurídico

$27 \quad$ El TCu advierte que un criterio distinto al expuesto, "podría llevar a extraer del ámbito de la contratación, prestaciones o servicios que constituyen su objeto propio. Tal como ocurriría si se considerara suficiente la mera declaración de la existencia de un interés compartido o la aportación por la Administración de medios existentes en sus dependencias o la constitución de un órgano de seguimiento para ignorar la naturaleza de una operación que, en el fondo, se traduce en satisfacer una cantidad a cambio de unas prestaciones que realiza el otro sujeto". Dictamen del TGu núm. 878, de 30 de noviembre de 2010, cit., p. 24.

28 En este sentido, Pascual García señala que, "habrá convenio si, concurriendo las demás condiciones, el objeto no fuera contractual, pero también lo habrá si, aun siendo contractual, falta una nota esencial de la definición de contrato. La diferencia entre el objeto del contrato y el del convenio no radica tanto en su materialidad como en la causa y en la forma de realizarlo, que no constituye contraprestación a cargo de una de las partes sino la participación de ambas en «un fin común» (art. 47 LRJSP) o en «un asunto de interés común», en expresión del art. 57 LBRL. Sólo las prestaciones onerosas, coincidentes con las contractuales, que se hacen solvendi causa, excluyen la figura del convenio; pero no las que, coincidentes materialmente o no con las contractuales, se hacen conveniendi causa (esto es en aras de la consecución de un fin común y sin onerosidad). Pascual García, J., "La regulación de los convenios administrativos en la Ley de Régimen Jurídico del Sector Público", Revista Española de Control Externo, vol. xvIII, núm. 54, 2016, p. 170.

29 Informe 5/2015, de 12 de mayo, de la Junta Consultiva de Contratación Administrativa de la Comunidad Autónoma de Aragón, sobre la posibilidad de realizar obras de electrificación por convenio, cuando se trata de prestaciones que constituyen el objeto de un contrato, p. 3.

30 Directiva 2014/23/UE de 26 de febrero de 2014, relativa a la adjudicación de contratos de concesión y la Directiva 2014/24/UE, de 26 de febrero de 2014 sobre contratación pública y por la que se deroga la Directiva 2004/18/CE, («DOUE» núm. 94, de 28 de marzo de 2014). 
español las Directivas referidas, aún sigue en el Senado ${ }^{31}$. Aun así, teniendo en cuenta la inminencia del nuevo texto y, en especial, los efectos que pueden derivarse de las Directivas desde su publicación, se examinan a continuación las diferencias existentes, en cuanto a la regulación de los convenios, entre la vigente y la futura LCSP ${ }^{32}$.

En primer lugar, el Proyecto de Ley establece una regulación más pormenorizada de los convenios excluidos del ámbito de aplicación de la legislación contractual ${ }^{33}$. Respecto a los convenios interadministrativos, el art. 6.1 del Proyecto de Ley difiere sustancialmente del actual art. 4.1.c) TRLCSP $^{34}$. En su primer párrafo se introduce

31 Las Directivas de contratación pública entraron en vigor a los 20 días de su publicación en el DOUE núm. 94, de 28 de marzo de 2014, concediendo un plazo máximo de transposición a los Estados miembros de dos años, esto es, el 18 de abril de 2016. Si bien, el procedimiento de transposición previsto en nuestro sistema jurídico, - a través de la tramitación ordinaria de un Proyecto de Ley preparado por el Gobierno de la Nación-, ha retrasado sustancialmente el cumplimiento de esta obligación. En este caso, el anteproyecto de Ley de Contratos del Sector Público, por la que se transponen al ordenamiento jurídico español las Directivas del Parlamento Europeo y del Consejo, 2014/23/UE y 2014/24/UE, de 26 de febrero de 2014, fue aprobado en Consejo de Ministros el 17 de abril de 2015 y remitido a las Cortes el 25 de noviembre de 2016. No fue hasta el 2 de diciembre de 2016 que se encomendó su aprobación, con competencia legislativa plena y por el procedimiento de urgencia, a la Comisión de Hacienda y Administraciones Públicas, publicándose el Proyecto de LCSP en el Boletín Oficial de las Cortes Generales, estableciendo un plazo de enmiendas que finalizaría el día 14 de diciembre de 2016. El pasado 27 de julio de 2017, el Congreso de los Diputados aprobó el Proyecto de LCSP, hoy en el Senado, donde a últimos de septiembre de 2017 aún está en proceso de enmiendas. Parece lógico pensar que a finales de este año dispondremos del nuevo texto normativo. Vid. BOCG, Senado, apartado I, núm. 151-1240, de 27 de septiembre de 2017.

32 De acuerdo con la jurisprudencia del TJUE, las Directivas que no hayan sido transpuestas dentro del plazo correspondiente resultan de aplicación directa si sus disposiciones tienen un contenido incondicional y son suficientemente claras y precisas. Sobre los efectos jurídicos de estas Directivas, antes de su efectiva transposición, vid. Gimeno FeLiu, J.M., "El efecto directo de las Directivas de contratación pública de 2014 en ausencia de transposición en plazo en España", Contratación administrativa práctica: revista de la contratación administrativa y de los contratistas, núm. 143, 2016; Tribunales Administrativos dE ConTratación Pública, Los efectos jurídicos de las Directivas de contratación pública ante el vencimiento del plazo de transposición sin nueva Ley de contratos públicos, OBCP, marzo de 2016, Madrid.

33 Como señala el Consejo de Estado, la tendencia de la legislación comunitaria y, por tanto, de la interna que se incorpora, es ir ampliando su ámbito subjetivo, y, por consiguiente, el número de entidades que quedan sujetas a sus previsiones. De acuerdo con esto, resulta paradójico que, en lo tocante al ámbito objetivo, el Proyecto de Ley, — siguiendo las directrices de la Directiva que incorpora-, amplíe el número de casos de contratos y convenios que quedan excluidos de sus previsiones. Cfr. Dictamen del Consejo de Estado núm.1.116/2015, de 10 de marzo de 2016, Anteproyecto de Ley de Contratos del Sector Público, p. 58.

34 De acuerdo con el art. 6.1 del Proyecto de LCSP, por la que se transponen al ordenamiento jurídico español las Directivas del Parlamento Europeo y del Consejo, 2014/23/UE y 2014/24/UE, de 26 de febrero de 2014: "1. Quedan excluidos del ámbito de la presente Ley los convenios que celebre la Administración General del Estado con las entidades gestoras y servicios comunes de la Seguridad Social, las mutuas colaboradoras con la Seguridad Social, las Universidades Públicas, las Comunidades Autónomas, las Entidades locales, organismos autónomos y restantes entidades públicas, o los que celebren estos organismos y entidades entre sí, siempre que su contenido no esté comprendido en el de los contratos regulados en esta Ley o en normas administrativas especiales. La exclusión requerirá, en la medida en que las entidades participantes en el convenio tengan el carácter de poderes adjudicadores, que el convenio desarrolle una cooperación entre aquellas con la finalidad de garantizar que los servicios públicos que les incumben se prestan de modo que se logren los objetivos que tienen 
una regla de exclusión de los convenios celebrados entre las entidades públicas que menciona, "siempre que su contenido no esté comprendido en el de los contratos regulados en esa Ley o en normas administrativas especiales". Se suprime con ello la referencia a la exclusión según la naturaleza contractual o no del convenio, prevista en el actual art. 4.1.c). Además, dada la mayor atención a la cooperación horizontal que prestan las Directivas, el art. 6.1, párrafo segundo, vincula la exclusión, en la medida en que las entidades participantes tengan el carácter de poderes adjudicadores, al cumplimiento de una serie de requisitos, a saber: i) que el convenio se dirija a establecer una cooperación entre los poderes adjudicadores para garantizar que los servicios públicos que les incumben se prestan de modo que se logren los objetivos que tienen en común; ii) que la aplicación de dicha cooperación se base únicamente en consideraciones relacionadas con el interés público; iii) y, que las citadas entidades realicen en el mercado abierto menos del 20 por ciento de las actividades objeto de colaboración ${ }^{35}$. De este modo, la exclusión prevista en el Proyecto de Ley se funda en la naturaleza especial de los convenios que no pueden, ni deben, someterse a las normas rígidas de la contratación administrativa, presididas por los principios de concurrencia, transparencia, publicidad y no discriminación ${ }^{36}$.

en común; que el desarrollo de dicha cooperación se guíe únicamente por consideraciones relacionadas con el interés público; y que las citadas entidades realicen en el mercado abierto menos del 20 por ciento de las actividades objeto de la colaboración. Para determinar el porcentaje de actividades, se aplicarán las reglas contenidas en la letra b) del apartado 2 del artículo 32. A efectos del cumplimiento del requisito establecido en el párrafo anterior sobre la realización en el mercado abierto de menos del 20 por ciento de las actividades objeto de la colaboración, las entidades pertenecientes al Sector Público participantes en el convenio, en la medida en que tengan el carácter de poderes adjudicadores, efectuarán una declaración responsable que formará parte de la documentación del convenio a suscribir".

35 Siguiendo las pautas marcadas por la Directiva 2014/24/UE, de 26 de febrero de 2014, "los poderes adjudicadores han de poder optar por prestar de manera conjunta sus servicios públicos mediante cooperación sin verse obligados a adoptar una forma jurídica particular. (...) Los contratos para la prestación conjunta de servicios públicos no han de estar sujetos a la aplicación de las normas establecidas en la presente Directiva, siempre que se hayan celebrado exclusivamente entre poderes adjudicadores, que la aplicación de dicha cooperación esté guiada únicamente por consideraciones de interés público y que ninguna empresa de servicios privada se encuentre en una situación ventajosa frente a sus competidores", (Consid. 33). De acuerdo con esto, el art. 12.4 de la Directiva dispone que, "un contrato celebrado exclusivamente entre dos o más poderes adjudicadores quedará fuera del ámbito de aplicación de la presente Directiva, cuando se cumplan todas y cada una de las condiciones siguientes: a) que el contrato establezca o desarrolle una cooperación entre los poderes adjudicadores participantes con la finalidad de garantizar que los servicios públicos que les incumben se prestan de modo que se logren los objetivos que tienen en común; b) que el desarrollo de dicha cooperación se guie únicamente por consideraciones relacionadas con el interés público, y c) que los poderes adjudicadores participantes realicen en el mercado abierto menos del $20 \%$ de las actividades objeto de la cooperación". Criterios que, como se ha visto, se integran en el art. 6.1 del Proyecto de LCSP.

36 En este sentido ya se pronunciaba la Junta Consultiva de Contratación Administrativa en su informe 18/2001, de 3 de julio de 2001, al afirmar que, "los convenios constituyen el modo normal de relacionarse las Administraciones Públicas, los Organismos autónomos y demás entidades públicas sujetas en su actividad contractual al régimen de dicha Ley, ya que, al no poder precisarse cuál de las partes debe actuar como órgano de contratación y cual como contratista, unido a la dificultad de aplicar a la Administración, organismo o ente que haya de considerarse que actúa como contratista preceptos concretos de la Ley (ca- 
Asimismo, se advierte un cambio importante en la dicción empleada en el nuevo art. 6.2 del Proyecto de Ley respecto a los convenios con personas físicas o jurídicas sujetas a derecho privado ${ }^{37}$. Se habla ahora de exclusión de la legislación contractual siempre que el contenido del convenio no esté comprendido en el de los contratos regulados en la Ley o normas administrativas especiales. Referencia que, homogeneizando los criterios utilizados en ambos supuestos, conduce claramente a los contratos típicos o administrativos atípicos por decisión legal ${ }^{38}$.

Por tanto, a la luz de la nueva redacción de los apartados 1 y 2 del art 6 del Proyecto de Ley, puede concluirse que la nota distintiva entre contratos y convenios reside en que, en estos últimos, la idea que prevalece es la de colaboración entre las partes para la consecución de un fin común que, dada la condición de Administración pública de una de las partes, deberá ser de interés público ${ }^{39}$. De acuerdo con esta

pacidad y solvencia, clasificación, garantías, etc .) resulta obligado canalizar estas actuaciones por la vía del convenio de colaboración y no del contrato". Informe de Junta Consultiva de Contratación Administrativa núm. 18/2001, de 3 de julio de 2001, sobre la posibilidad de que una Mancomunidad de municipios figure como licitadora en un concurso de una Diputación Provincial para la adjudicación de un contrato para recogida de residuos y limpieza de caminos, pp.1-2.

37 De acuerdo con el art. 6.2. del Proyecto de LCSP, "estarán también excluidos del ámbito de la presente Ley los convenios que celebren las entidades del sector público con personas fisicas o jurídicas sujetas al derecho privado, siempre que su contenido no esté comprendido en el de los contratos regulados en esta Ley o en normas administrativas especiales".

38 El Proyecto de LCSP corrige la disfunción existente entre los criterios empleados en los apartados 1 y 2 del art. 6 del Anteproyecto de LCSP. Así, mientras que en el art. 6.1 del Anteproyecto se establecía la exclusión del convenio "salvo que por su contenido y causa tengan la consideración de contratos sujetos a esta Ley, en cuyo caso deberá considerarse como tales, aplicándose las prescripciones de esta norma”, el apartado segundo recogía el criterio, hoy común, de excluir los convenios "siempre que el contenido del convenio no este comprendido en el de los contratos regulados en la Ley o normas administrativas especiales". Esta diferencia de criterios conducía, a juicio del Consejo de Estado a que "los entes públicos no puedan celebrar convenios entre sí si tienen la consideración de contratos sujetos a la ley (todos los onerosos). Por el contrario, y respecto de los convenios celebrados entre las entidades públicas y los sujetos de derecho privado, solo quedan vedados si se insertan en el ámbito de los contratos regulados en la ley o en las normas administrativas especiales. Así las cosas, resulta que es más fácil que las entidades públicas celebren convenios de colaboración con personas sujetas a derecho privado que con otros entes públicos, lo que carece de sentido". Cfr. Dictamen del Consejo de Estado núm.1.116/2015, de 10 de marzo de 2016, cit., p. 64.

39 En este sentido, el Consejo de Estado, teniendo en cuenta las previsiones del art. 47 LRJSP y la jurisprudencia del TS, sostiene que, "la característica diferenciadora de los convenios frente a los contratos radica en que, frente al modelo clásico de los contratos en que se da un antagonismo patrimonial en las prestaciones de las partes, los convenios responden a la idea de colaboración en la consecución del fin común. Inherentes a la noción de contrato son, de una parte, la emisión de declaraciones de voluntad intrínsecamente diferentes por parte de los contratantes pero que se corresponden entre sí y que coinciden en la obtención de un mismo efecto jurídico y, de otro lado, la equivalencia de prestaciones o su carácter sinalagmático. En los convenios, por el contrario, la idea prevalente es la de colaboración entre las partes para la consecución de un fin común. Las partes no se enfrentan como portadoras de intereses contrapuestos y, de ordinario, no emiten declaraciones de voluntad intrínsecamente diferentes sino generalmente iguales". Cfr. Dictamen del Consejo de Estado núm.1.116/2015, de 10 de marzo de 2016, cit., pp. 62-63. 
interpretación, y siguiendo aquí a SANTIAgo IgLESIAS, “un negocio jurídico tendrá naturaleza convencional cuando, aun coincidiendo su objeto con el de alguno de los contratos regulados en el TRLCSP, las Administraciones públicas intervinientes lo celebren con la finalidad coordinar, cooperar o auxiliarse en la planificación o ejecución de las actuaciones que pretenden desarrollar, es decir, cuando persigan un objetivo común de interés público, mientras que el negocio jurídico de que se trate tendrá naturaleza contractual cuando con él se persiga, prevalentemente, el lucro de una de las partes" ${ }^{\prime 0}$. Por lo tanto, en línea con la interpretación del actual art. 4 TRLCSP, puede entenderse confirmada la irrelevancia del objeto del negocio jurídico debiendo centrarse la atención en el fin que se persigue.

\section{B. El nuevo concepto de convenio}

La LRJSP inicia la regulación de los convenios precisando su definición en el art. 47, donde se refiere a esta figura como aquellos "acuerdos con efectos jurídicos adoptados por las Administraciones Públicas, los organismos públicos y entidades de derecho público vinculados o dependientes o las Universidades públicas, entre sí o con sujetos de derecho privado para un fin común". Por tanto, se trata de un negocio jurídico, de un pacto colaborativo, encauzado a la consecución de un fin de interés público, concreto y común, en el que se determinan las obligaciones, - de dar o hacer - y derechos que las partes deben satisfacer, sin que exista por ello un precio como contraprestación ${ }^{41}$. Ahora bien, como señala MuÑoz-Charles Coyle, "ello no impide que del convenio resulte una financiación conjunta y determinada de proyectos o actuaciones concretas para alcanzar la finalidad prevista" ${ }^{\prime 2}$.

Como es lógico, si los convenios son negocios jurídicos que incluyen compromisos específicos y obligaciones concretas que deben satisfacerse, cuyo incumplimiento, además, puede conducir a los tribunales, deben quedar fuera del ámbito de aplicación de la LRJSP los Protocolos Generales de Actuación, o instrumentos similares, que no incluyan, en ninguna de sus cláusulas, compromisos jurídicos concretos y exigibles. En este sentido, pueden plantear dudas los denominados «convenios marco»,

40 Santiago Iglesias, D., "Las relaciones de ...", cit., p. 16.

${ }_{41}$ Se habla de un fin de interés público presente que, en todo caso, una de las partes del convenio ha de ser Administración pública. Asimismo, la exigencia de que los convenios satisfagan un fin común requiere cierta reflexión puesto que, según se interprete este concepto, el ámbito de los convenios puede ser mayor o menor. Como señala Muñoz-Charles CoYle, "si se interpreta como fin común la causa de obligaciones que se establezcan, en los términos que define el art. $1261 \mathrm{CC}$, para la existencia de todo contrato, el elenco de posibles convenios será mayor que para el caso de que tengan lugar otro tipo de interpretaciones, como, por ejemplo, la puesta en común de medio para emprender una determinada actuación". Muñoz-Gharles Coyle, M.L., "La nueva regulación de los convenios entre Administraciones Públicas y particulares", Actualidad jurídica Aranzadi núm. 914/ 2015, p. 2.

42 Muñoz-Charles Coyle, M.L., "La nueva regulación ...", cit., p. 3. 
que establecen directrices vinculantes para las partes que deberán desarrollarse en un convenio posterior. Dado el carácter de estos convenios marco no estamos ante meras declaraciones de intención, sino que, como señala Pascual García, "su papel es equiparable a las cláusulas administrativas generales en la contratación”43.

El precepto también recoge, de forma expresa y categórica, que los convenios no pueden tener por objeto prestaciones propias de los contratos. De lo contrario, su naturaleza y régimen jurídico deberá ajustarse a lo previsto en la legislación de contratos del sector público. Con ello, no sólo se subraya la diferencia entre contratos y convenios, en aras de poner fin a determinadas prácticas irregulares, sino que se alberga un reenvío indirecto a la legislación contractual como línea divisoria entre ambas figuras.

Si bien, pese a lo oportuno del nuevo concepto de convenio y su pretendida diferenciación con los contratos, no puede entenderse que la LRJSP cumpla de forma plena con la recomendación efectuada por el TCu de establecer una mejor distinción de los convenios de otras figuras afines. Una diferenciación que, como señaló el CGPJ, hubiera sido "más acorde con la voluntad declarada de establecer un marco clarificador en la materia que sirva para evitar la posibilidad de utilización de este instrumento de colaboración para soslayar la aplicación de otras figuras" ${ }^{\text {44 }}$. Aun así, se aprecian pasos incipientes en esta línea como, por ejemplo, en el art. 48.9 LRJSP donde se señala que, "las normas del presente Capitulo (referidas a los convenios) no serán de aplicación a las encomiendas de gestión y los acuerdos de terminación convencional de los procedimientos administrativos".

Por lo que se refiere a la encomienda de gestión, cabe recordar que no se trata de una figura jurídica pacífica. A la complejidad de haber acogido bajo una misma denominación dos realidades jurídicas distintas, sujetas a dos regímenes jurídicos diferenciados, se le añade, además, el hecho de que la encomienda de gestión deba, según el caso, instrumentalizarse o no a través de un convenio. Por ello, junto con la distinción entre las encomiendas de gestión previstas en el art. 11 LRJSP (anterior, art. 15 LRJ-PAG) y las encomiendas de gestión a entes instrumentales (arts. 4.1.n y 24.6 TRLCSP), resulta esencial establecer una línea de separación entre estas y los $\operatorname{convenios}^{45}$.

43 Pascual García, J., "La regulación de...", cit., p. 161.

44 CGPJ, Secretaria General, Informe al Anteproyecto de Ley de Régimen furídico del Sector Público, Madrid, 5 de marzo de 2015, p. 48.

45 La encomienda de gestión fue, en origen, objeto de regulación general en el art. 15 LRJPAC, que habilitó la posibilidad de llevar a cabo encomiendas de gestión para la realización de actividades de carácter material, técnico o de servicios de la competencia de los órganos administrativos o de las Entidades de Derecho público, a favor de otros órganos o Entidades de la misma o de distinta Administración, por razones de eficacia o cuando no se poseyeran los medios técnicos idóneos para su desempeño. El recurso a 
En primer lugar, la LRJSP distingue las encomiendas de gestión de los convenios al regular ambas figuras en capítulos distintos de la Ley. Las encomiendas de gestión, de acuerdo con lo establecido en el art. 11 LRJSP, se refieren a la posibilidad de que las actividades de carácter material o técnico de la competencia de los órganos administrativos o de las entidades de derecho público, puedan encomendarse a otros órganos o entidades de derecho público, de la misma o de distinta Administración, por razones de eficacia o cuando no se posean los medios técnicos idóneos para su desempeño. Por lo tanto, el hecho de que, según el caso, estas encomiendas de gestión deban instrumentalizarse a través de un convenio, no es más que un punto de conexión que en nada debe contribuir a la confusión de estas figuras ${ }^{46}$.

esta figura se limitó en exclusiva al marco administrativo, al excluir la posibilidad de efectuar encomiendas cuando la realización de las actividades técnicas, de servicio, o de carácter material fueran a llevarse a cabo por personas de Derecho privado debiendo, en ese caso, ajustarse a la legislación de contratos. Así las cosas, el Real Decreto-Ley 5/2005, de 11 marzo, de reformas urgentes para el impulso a la productividad y para la mejora de la contratación pública, recurrió, en su art. 34, al uso del término encomiendas de gestión, ya utilizado en el art. 15 LRJ-PAC, para referirse a los encargos de contenido contractual realizados a entidades instrumentales de una Administración excluyéndolas del ámbito de aplicación del TRLCAP, pero sin identificar, ni establecer, el régimen jurídico aplicable a las mismas. A partir de este momento, la legislación de contratos ha ido modulando, con distinto grado de precisión, la exclusión de este tipo de encomiendas de su ámbito de aplicación. De conformidad con lo expuesto, bajo la denominación de encomiendas de gestión se albergaron dos realidades distintas, de un lado, las encomiendas de gestión del art. 15 LRJ-PAC, circunscritas a aquellas actividades o actuaciones que, por su contenido, son ajenas a la legislación de contratación pública y no guardan relación con ella; y de otro, las encomiendas de gestión prevista en los arts. 4.1.n) y 24.6 TRLCSP, referidas a aquellas actuaciones consistentes en la realización de prestaciones propias del contrato de obras, suministros y servicios a cambio de una contraprestación económica. Por lo tanto, ambas encomiendas de gestión se refieren a figuras dispares, diferenciadas por su ámbito objetivo, — materialmente contractual o no- - y sujetas a regímenes jurídicos igualmente diferenciados. En este sentido, vid. Circular 6/2009, "Asunto: Relación entre el art. 15 LRJ-PAC y el art. 24.6 LCSP, en la que se recoge el Informe de la Abogacía General del Estado, de 26 de noviembre de 2008; Informe del Tribunal de Cuentas, de 30 de abril de 2015, sobre Fiscalización de las encomiendas de gestión de determinados Ministerios, Organismos y otras Entidades Públicas llevadas a cabo al amparo de la legislación que habilita esta forma instrumental de gestión administrativa.

46 La LRJSP despeja toda duda sobre el adecuado vehículo de formalización de las encomiendas de gestión en el art. 11. De conformidad con el citado precepto i) las encomienda de gestión intradministrativa, esto es, la realizada entre órganos administrativos o Entidades de Derecho Público pertenecientes a la misma Administración, deberán formalizarse en los términos que establezca su normativa propia y, en su defecto, por acuerdo expreso de los órganos o Entidades de Derecho Público intervinientes; ii) cuando se trate de una encomienda de gestión interadministrativa, la realizada entre órganos y Entidades de Derecho Público de distintas Administraciones, se formalizará mediante la firma del correspondiente convenio. Por lo tanto, no siempre que se formaliza una encomienda de gestión se suscribe un convenio. Sin embargo, el Consejo de Estado no lo ha entendido así, y, con ocasión de su Dictamen al Anteproyecto de Ley, señala expresamente que, "el art. 22.9 del Anteproyecto debería ser reformulado. Este precepto establece que «las encomiendas de gestión y los acuerdos de terminación convencional a los que se refiere la Ley del Procedimiento Administrativo Común de las Administraciones Públicas, que se formalicen mediante un convenio, se regirán por lo dispuesto en esa Ley». Sin embargo, la redacción del precepto en cuestión no es afortunada; en primer lugar, porque da a entender que no todas las encomiendas de gestión y acuerdos de terminación 
Asimismo, el convenio y las encomiendas de gestión a entes instrumentales (art. 4.1.n TRLCSP) son figuras negociales diferenciadas. En contra de lo que acontece en el convenio, donde las partes se sitúan en un plano de igualdad, las encomiendas de gestión a medio propios se formalizan entre sujetos que no son materialmente independientes, aunque formalmente si lo sean, por lo tanto, se trata de un mandato que debe ser asumido. Pero, además, establecida así la diferencia, la LRJSP pone fin a toda posible confusión entre encomienda de gestión y los encargos a medios propios que ahora regulados ahora en el art. $86 \mathrm{LRJSP}^{47}$.

Esta diferenciación no resulta tan sencilla en relación con los convenios transaccionales. De acuerdo con las previsiones del art. 86 LPACAP, la terminación de un procedimiento administrativo puede alcanzarse a través de la celebración de un convenio entre una Administración pública con personas tanto de derecho público como privado. En este caso, pese a quedar excluidos de la aplicación del régimen jurídico de los convenios, en los mismos términos que las encomiendas de gestión, hay quien advierte diferencias importantes. Así, Menéndez Rexach apunta que, mientras que la terminación convencional tiene sustantividad propia frente a otro tipo de convenios, la encomienda de gestión carece de ella, pudiendo quedar comprendida en varios de los tipos legales previstos ${ }^{48}$. De acuerdo con esto, el referido autor aboga por incluir los convenios transaccionales como una categoría más de convenio.

Junto con esto, debe tenerse en cuenta aquí las consideraciones del TCu que, en relación a la terminación convencional de procedimientos, puso de manifiesto que, "aun cuando la doctrina que se ha ocupado del estudio del art. 88 LRJ-PAC (86 LPAC) no lo relaciona con la regulación de los convenios por la LCSP, no parece que

convencional se formalizan mediante convenio, cuando, en realidad, éste siempre existe en tales casos, y, en segundo término, porque, en lugar de remitir la regulación de las encomiendas de gestión y los acuerdos de terminación convencional a lo dispuesto en la Ley del Procedimiento Administrativo Común, debería exceptuar a tales figuras de la aplicación del régimen de los convenios de colaboración contenido en la Ley de Régimen Jurídico del Sector Público". Dictamen del Consejo de Estado núm. 274/2015, de 29 de abril, cit.

47 En este sentido, Colás Tena, partiendo de la definición positiva de encomienda de gestión facilitada en el art. 11 LRSJP, proporciona una en sentido negativo, señalando que, "las encomiendas de gestión no podrán tener por objeto prestaciones propias de los contratos regulados en la legislación de contratos del sector público. En tal caso, su naturaleza y régimen jurídico se ajustará a lo previsto por esta, y se articularán a través de los encargos a los medios propios y servicios técnicos que se regulan en el art. 86 del mismo texto legal. Ello es así porque las denominadas encomiendas de gestión a medios propios y servicios técnicos de las Administraciones Públicas constituyen un instrumento de aprovisionamiento de obras, bienes y servicios de las Administraciones y entidades públicas que se encuentra previsto normativamente en la legislación de contratos del sector público, a partir del impulso jurisprudencial del TJUE". Colás TenA, J., "Encomiendas de gestión, encargos y convenios en la Ley 40/2015, de 1 de octubre, de Régimen jurídico del Sector Público", Cuadernos de Derecho Local, núm. 41, 2016, pp.160-161.

48 Menéndez Rexach, A., "Encomiendas de gestión y convenios", Cuadernos de Derecho Local, núm. 41, 2016, p. 144 . 
el ámbito de aplicación de este precepto deba limitarse a los denominados convenios procedimentales, sino que puede comprender toda clase de materias, con los límites que el precepto expresa. No otro sentido puede tener la remisión al «alcance, efectos y régimen jurídico específico que en cada caso prevea la disposición que lo regule». Así pues, dentro de los negocios jurídicos regulados por el reproducido artículo se pueden comprender diversas figuras (acuerdos, pactos, convenios o contratos), entre las cuales se encontrarían, como una más de las posibles, los contratos y los convenios administrativos entre personas tanto de derecho público como privado, regulados en la LCSP"49. La LRJSP podría haber desarrollado con mayor claridad la distinción entre los convenios que ponen fin a los procedimientos administrativos y los regulados bajo el régimen previsto en el Capítulo vi del Título preliminar.

\section{La nueva clasificación de los convenios}

Junto con el nuevo concepto de convenio, la LRJSP introduce una novedosa clasificación que deja atrás la tradicional distinción entre convenios de colaboración y de cooperación. El art. 47 LRJSP distingue ahora cuatro tipos de convenios entre los que deberán hallar correspondencia cualquiera de los firmados por las Administraciones públicas, los organismos públicos y entidades de derecho público vinculadas o dependientes y las Universidades públicas (numerus clausus). En concreto, la nueva regulación se refiere a los siguientes:

Convenios interadministrativos, los firmados entre dos o más Administraciones públicas, o bien entre dos o más organismos públicos o entidades de derecho público vinculados o dependientes de distintas Administraciones públicas, y que podrán incluir la utilización de medios, servicios y recursos de otra Administración pública, organismo público o entidad de derecho público vinculado o dependiente, para el ejercicio de competencias propias o delegadas. Además, cumpliendo con lo dispuesto en el art. 145.2 CE, el precepto excluye, de entre los convenios interadministrativos, los suscritos entre dos o más CCAA para la gestión y prestación de servicios propios de las mismas. Estos se regirán, en cuanto a sus supuestos, requisitos y términos, por lo previsto en sus respectivos Estatutos de Autonomía ${ }^{50}$.

49 Dictamen del TGu núm. 878, de 30 de noviembre de 2010, cit., pp. 19-20. Para Fuertes López, en el caso de convenios con particulares que han surcado el recorrido de unos trámites procedimentales, esta previsión "tiene la virtud de subrayar que no debe el contenido de ese acuerdo, propiciado por una adhesión negociadora de los interesados, salirse de los rieles que justificó el procedimiento administrativo, fruto del ejercicio de potestades y competencias públicas. El contenido del acuerdo no podrá suponer una renuncia, una dejación de funciones públicas. Que se haya conseguido la aquiescencia del particular, tras la sucesión de trámites procedimentales, no puede ser un cauce para eludir responsabilidades públicas". Fuertes López, M., "Los convenios y los consorcios ...", cit., p. 16.

50 Con la exclusión de los convenios interautonómicos para la gestión y prestación de servicios propios, la LRJSP salva una posible causa de inconstitucionalidad, por infracción del art. 145.2 CE, ad- 
Convenios intradministrativos, los firmados entre organismos públicos y entidades de derecho público vinculados o dependientes de una misma Administración pública. La LRJSP otorga así carta de naturaleza a unos convenios no siempre claros. El propio TCu llegó a plantear la incertidumbre relativa a la consideración como tales de los convenios celebrados entre un Ministerio y las entidades adscritas al mismo. Dudas finalmente resueltas, al considerar el Alto Tribunal que, "la relación de dependencia o instrumentalidad del organismo público pugna con la nota de igualdad de los suscriptores, propia de los convenios interadministrativos" $"$. En estos casos, como señala PAscual García, nos encontramos ante supuestos de coordinación interorgánica de naturaleza distinta a las relaciones intersubjetivas que se establecen a través de los convenios ${ }^{52}$.

Convenios firmados con un sujeto de derecho privado, aquellos firmados entre una Administración pública u organismo o entidad de derecho público con personas físicas o jurídicas sujetas al derecho privado. En relación con estos, han sido tradicionales las dudas sobre los convenios celebrados con entidades que, pese a ser públicas, se rigen por el derecho privado, — como las entidades públicas empresariales-, o aquellas que, perteneciendo al sector público, no alcanzan la condición de entidad de derecho público, - tal y como ocurre con las fundaciones o sociedades mercantiles de participación mayoritaria o exclusivamente pública-. El TCu concreta los criterios para la correcta clasificación del convenio y mantiene que, lo relevante para que el convenio quede encuadrado como «convenio con particulares», en positivo, es que las personas con las que se suscriben queden sometidas al derecho privado, y, en negativo, que no sean entidades públicas. De acuerdo con esto, los convenios con las entidades públicas empresariales serían convenios interadministrativos, mientras que, en el caso de las fundaciones o las sociedades mercantiles señaladas, se estaría

vertida por el Consejo de Estado en su Dictamen núm. 274/2015, de 29 de abril. Así, mientras que el régimen jurídico básico de los convenios que recoge la LRJSP encuentra su amparo constitucional en el art. 148.1.19a - que reconoce a favor del Estado la competencia básica sobre el régimen jurídico de las Administraciones Públicas-, el art. 145.2 CE reserva la regulación de estos convenios interautonómicos a las normas estatutarias de las CCAA. En ese sentido, establece el citado precepto que, "los Estatutos podrán prever los supuestos, requisitos y términos en que las Comunidades Autónomas podrán celebrar convenios entre sí para la gestión y prestación de servicios propios de las mismas, asi como el carácter y efectos de la correspondiente comunicación a las Cortes Generales. En los demás supuestos, los acuerdos de cooperación entre las Comunidades Autónomas necesitarán la autorización de las Cortes Generales". En realidad, como señala el TC, el art. 145.2 CE "no es un precepto que habilite a las Comunidades para establecer convenios entre ellas, sino que, supuesta esa capacidad, delimita por su contenido los requisitos a que ha de atenerse la regulación de esta materia en los Estatutos y establece el control por las Cortes Generales de los acuerdos o convenios de cooperación, (STC 44/1986, de 17 de abril, FJ2).

51 Dictamen del TGu núm. 878, de 30 de noviembre de 2010, cit., pp. 17-18.

52 Pascual García, J., Convenios de colaboración..., cit., p. 113. 
ante convenios con sujetos de derecho privado ${ }^{53}$. Si bien, debe tenerse en cuenta aquí que, los convenios suscritos con fundaciones públicas, sociedades mercantiles y otros medios propios de la Administración y los celebrados con personas puramente privadas, tienen un significado muy diferente. Como señala Menéndez Rexach, "los primeros se asimilan a los de cooperación (inter o intradministrativos), mientas que, en los segundos, la parte privada es ajena a la Administración, o si se prefiere, al Sector Público" ${ }^{54}$.

Convenios no constitutivos ni de Tratado internacional, ni de Acuerdo internacional administrativo, ni de Acuerdo internacional no normativo que puedan firmar entre sí las Administraciones públicas y los órganos, organismos públicos o entes de un sujeto de Derecho internacional, lo cuales se regirán por el ordenamiento jurídico interno que determinen las partes y que deberá especificarse en el propio convenio ${ }^{55}$.

Dejando de lado lo conveniente o no de haber conservado la sola distinción entre «convenios interadministrativos» y «convenios Administración-administrados», la tipología recogida en el art. 47.2 LRJSP se ha tildado de incompleta ${ }^{56}$. Se cuestiona

\footnotetext{
53 Respecto de los convenios celebrados con entidades de derecho público regidas por el Derecho privado, el TCu aclara que, "los organismos públicos, aun cuando en sus relaciones ad extra se rijan por el Derecho privado, con la Administración centralizada de la que constituyen entes instrumentales o con otras Administraciones Públicas establecen relaciones jurídicas que no parece que deban situarse en el plano de las relaciones administrativas con particulares, sino en el de "entidades públicas" que se rijan por el Derecho privado, las interadministrativas". Asimismo, respecto de los convenios celebrados con entidades que, perteneciendo al Sector Público, no alcanzan las condición de entidad de derecho público, el Alto Tribunal concreta que, se han de entender comprendidos en los convenios con sujetos de Derecho privado, "los celebrados con las sociedades mercantiles de participación mayoritaria o exclusivamente pública y las fundaciones públicas, cuya pertenencia al Sector Público no les confiere la condición de Administración ni aun de entidades públicas". Dictamen del TGu núm. 878, de 30 de noviembre de 2010, cit., p.17.

54 Menéndez Rexach, A., "Encomiendas de gestión ...”, cit., p. 145.

55 Forman parte de esta categoría los denominados convenios de cooperación transfronterizos. Para la correcta definición de las figuras de Tratado internacional, Acuerdo internacional administrativo, Acuerdo internacional no normativo, vid., art. 2 de la Ley 25/2014, de 27 de noviembre, de Tratados y otros Acuerdos Internacionales, (BOE núm. 288, de 28 de noviembre de 2014).

56 En este sentido, Menéndez Rexach sostiene que, "se debería haber partido de la distinción, ya asentada, entre convenios interadministrativos y con sujetos de Derecho privado, subdividiendo los primeros en función de que se suscriban entre distintas Administraciones Públicas o en el seno no de una sola (lo que la Ley llama "intradministrativos"), y los segundos, en función de que el sujeto de Derecho privado sea un medio propio de una Administración o un particular (persona física o jurídica)". Menéndez REXACH, A., "Encomiendas de gestión ...", cit., p. 143. El autor se refiere aquí a la clasificación de los convenios de colaboración recogida hasta ahora en el TRLCSP y la LRJ-PAC, de acuerdo con la cual, los convenios de colaboración se clasificaban en dos tipologías principales: i) los que celebre la AGE con la Seguridad Social, las CCAA, las Entidades Locales, sus respectivos organismos autónomos y las restantes entidades públicas o cualesquiera de ellas entre sí. Siendo estos, como señala el TCu, los «convenios interadministrativos», y dentro de los cuales cabe, a su vez, diferenciar, como un subgrupo, los «intraadministrativos»; y, ii) los que celebre la Administración con personas físicas o jurídicas sujetas al Derecho privado, o más sencillamente
} 
la exclusión, vía art. 48.9 LRJSP, de los convenios que ponen fin a los procedimientos administrativos, señalándose que la terminación convencional posee, en realidad, sustantividad propia suficiente para reconocerla como un tipo específico dentro de esta nueva clasificación ${ }^{57}$. En todo caso, como señala GARCíA LuENGO, del análisis de esta tipología y de la exclusión de los principales contratos sobre potestades administrativas con particulares (los convenios transaccionales) se deduce que, "el modelo en el que está pensando el legislador es más bien el de la cooperación institucional entre diversos entes para la consecución de fines públicos, por más que alguno pueda tener personificación privada" ${ }^{\prime 58}$.

\section{Requisitos de validez y eficacia de los convenios}

La LRJSP enumera, en el art. 48, los presupuestos exigibles para la validez y eficacia de los convenios. Estos requisitos, que deben completarse con otros mandatos legales recogidos a lo largo del Capítulo vi, pueden sintetizarse en los siguientes: i) competencia para suscribir el convenio; ii) perfeccionamiento, inscripción y publicación; iii) adecuación de los convenios a los propósitos que persigue la reforma y los principios que informan la Ley.

En primer lugar, la norma reconoce la capacidad para suscribir convenios de las Administraciones públicas, sus organismos públicos y entidades de derecho público vinculados o dependientes y las Universidades públicas, haciéndolo "en el ámbito de sus respectivas competencias, sin que ello pueda suponer cesión de la titularidad de la competencia”. A través de esta fórmula, se integra en el texto legislativo, la jurispru-

llamados «convenios Administración-administrados». Cfr. Informe del TGu núm. 862, de 24 de junio de 2010, sobre fiscalización de los convenios de colaboración generadores de gastos suscritos a partir del año 2005 por órganos del Ministerio de Medio Ambiente con entidades públicas y con personas físicas o jurídicas privadas, p. 15 .

57 De acuerdo con esto, Menéndez Rexach lleva a cabo su propia clasificación de esta figura señalando que, "los tipos de convenios son: a) de cooperación, en las dos modalidades de interadministrativos o intradministrativos. En el primer grupo se incluyen los que se suscriban con órganos o entidades de otros Estados o de un sujeto de Derecho internacional, y que se rigen por el ordenamiento interno que en cada caso se determine; b) con sujetos de Derecho privado, que pueden ser entes instrumentales o medios propios de una Administración (en cuyo caso se asimilan a los convenios de cooperación), o personas físicas o jurídicas ajenas a ella (en cuyo caso deberían tener un régimen diferente, en especial, en cuanto a la aplicación obligatoria de los principios de publicidad y concurrencia); c) de terminación del procedimiento, que se rigen por el art. 86 LPAC y la disposición que en cada caso prevea esta modalidad de terminación". Menéndez Rexach, A., "Encomiendas de gestión ...”, cit., p. 145.

58 García Luengo, J., "Instituciones sustantivas en la Ley 40/2015, de régimen jurídico del sector público: los principios de la potestad sancionadora, la responsabilidad administrativa y el nuevo régimen de los convenios administrativos", El Cronista del Estado Social y Democrático de Derecho, núm. 63, 2016, pp. 14-27; disponible en http://laadministracionaldia.inap.es/noticia.asp?id=1506842 (fecha de última consulta, 9 de enero de 2017). 
dencia constitucional por la que se concreta que, los convenios solo pueden referirse a materias de la competencia de las Administraciones que los suscriben y no pueden suponer la renuncia de sus propias competencias, ni alterar de manera directa o indirecta el régimen constitucional de competencias ${ }^{59}$. Además, se cumple con el art. 140 LRJSP que, dentro de los principios que ha de regir las relaciones interadministrativas, prevé, de forma expresa, la adecuación al orden de distribución de competencias establecido en la CE, los EEAA y en la normativa de régimen local ${ }^{60}$.

Asimismo, la Ley prevé que los convenios, como negocios jurídicos que son, se perfeccionan por el consentimiento de las partes ${ }^{61}$. Ahora bien, aun suscritos y perfeccionados, la LRJSP advierte que, los convenios en los que participe la AGE o alguno de sus organismos públicos o entidades de derecho público vinculados o dependientes, solo serán eficaces una vez inscritos en el Registro Electrónico estatal de Órganos e Instrumentos de Cooperación (Disposición adicional $7^{\mathrm{a}}$ ) y publicados en el BOE. Nada se dice, sin embargo, respecto de los convenios firmados por el resto de Administraciones públicas. El art. 48 LRJSP no especifica si estos convenios están sujetos o no, para su validez, a la obligación de inscribirlos en algún registro.

59 En este sentido, la STC 13/1992, 6 de febrero, concreta en su FJ 10 que, "la fórmula del convenio responde a ese principio de cooperación inherente al Estado de las Autonomías y en el que debería profundizarse. Pero es obvio que no puede servir para que el Estado recupere competencias en sectores de actividad descentralizados por completo, pues como ya se dijo en la STC 96/1986, FJ 3. «es evidente que, con base en este deber de reciproco apoyo y mutua lealtad (que es el deber general de colaboración a que están sometidos el Estado y las CCAA), no pueden resultar ampliadas las competencias del Estado, ni es posible por lo mismo limitar o condicionar el ejercicio de las competencias autonómicas sobre esta materia (agricultura) a la celebración o cumplimiento de convenio alguno entre las dos administraciones territoriales». ni tampoco es admisible, como se dijo en la STC 95/1986, FJ 5, que merced a dicho convenio, la comunidad autónoma «haya podido renunciar a unas competencias que son indisponibles por imperativo constitucional y estatutario»". Siguiendo la línea anterior, la Audiencia Nacional ha reiterado que, "los convenios de colaboración en ningún caso suponen la renuncia a las competencias propias de las Administraciones intervinientes, o, como dijera el TC en su Sentencia 214/1989, de 21 de diciembre, «sin alterar, en ninguno de los casos la titularidad y el ejercicio de las competencias propias de los entes en relación»". SAN 317/2015, de 26 octubre FJ 3; 229/2015, 17 de julio, FJ 5; 198/2015, de 13 de julio, FJ 6.

60 Para determinar los órganos competentes para la suscripción del convenio deberá acudirse a la legislación propia de cada Administración Pública. En el art. 48.2 LRJSP se concreta que en el ámbito de la AGE y sus organismos públicos y entidades de derecho público vinculados o dependientes, podrán celebrar convenios los titulares de los Departamentos Ministeriales y los Presidentes o Directores de las dichas entidades y organismos públicos. En el ámbito local, corresponderá preferentemente al Alcalde suscribir los convenios en ejercicio de sus competencias de dirección y representación del Ayuntamiento. En este sentido, vid. Fuertes López, M., "Los convenios y los consorcios ...", cit., pp. 19 y ss; Colás Tena, J., "Encomiendas de gestión...”, cit., pp. 174-179.

61 Sobre el perfeccionamiento escrito de los convenios, Pascual García mantiene que "la prestación del consentimiento se expresa en el acto de su firma o suscripción por los sujetos que convienen, de manera que puede afirmarse que la suscripción es lo que da vida al convenio. El convenio se perfecciona y adquiere fuerza vinculante a partir de su formalización escrita". PAscual García, J., "La regulación de ...", cit., p. 179. 
Pese al mutismo del precepto, deben tenerse en cuenta aquí las exigencias de transparencia de la actuación pública y las técnicas de cooperación previstas en la LRJSP, predicables a todas las Administraciones. Tal y como dispone el art. 144.3 LRJSP, cada Administración pública deberá mantener actualizado un registro electrónico de los órganos de cooperación en los que participe y de los convenios que haya suscrito. Por lo tanto, existe una obligación, común a todas las Administraciones, de hacer público y accesible el contenido de los convenios que se suscriban. Ahora bien, sujetar la eficacia de los convenios a la obligada inscripción a estos registros, es una cuestión que escapa competencialmente de las manos del legislador estatal, debiendo determinarse, de forma potestativa, por la legislación correspondiente. Cuestión que, en identidad de término, se aprecia en relación a la publicación de los convenios en los Boletines autonómicos o provinciales.

En tercer lugar, debe tenerse en cuenta que los convenios, para ser válidos y eficaces, deberán ser acordes con los propósitos que persigue la reforma y los principios que informan la Ley. La norma especifica que la suscripción de un convenio ha de mejorar la eficiencia de la gestión pública, facilitar la utilización conjunta de medios y servicios públicos y cumplir con la legislación de estabilidad presupuestaria y sostenibilidad financiera (apartado 3); reitera que todas las actuaciones económicas deben satisfacer la legislación presupuestaria (apartado 4); que los convenios deben ser financieramente sostenibles por las Administraciones que los suscriban durante todas su vigencia (apartado 5); concretando que, si el convenio instrumenta una subvención, deberá cumplir con lo previsto en la Ley 38/2003, de 17 de noviembre, General de Subvenciones y en la normativa autonómica de desarrollo que, en su caso, resulte aplicable; así como con lo dispuesto en la Ley 7/1985, de 2 de abril, Reguladora de las Bases de Régimen Local, art. 27, cuando el convenio tenga por objeto la delegación de competencias en una Entidad Local (apartado 7). Especial importancia reviste el apartado $6 \mathrm{del}$ art. 48, en el que se concreta que, las aportaciones financieras que se comprometan a realizar los firmantes no podrán ser superiores a los gastos derivados de la ejecución del convenio. Esta precaución responde a los abusos en el gasto público que han caracterizado el ámbito de los convenios. Si bien, habrá ocasiones en las que, al tiempo de firmar el convenio, no sea posible determinar el importe exacto del gasto. En este caso, mantiene el TCu que, al menos, debería figurar el importe máximo del compromiso por exigencias de legalidad presupuestaria ${ }^{62}$. Sin embargo, debe imperar la lógica evitando alejar al convenio de la realidad. Como señala Fuertes López, aun cuando las cuentas deben ser claras y contenidas desde el principio, "habrá que admitir que circunstancias nuevas y totalmente imprevistas, que exigencias de responsabilidad patrimonial, puedan incrementar la factura del

62 Dictamen del TCu núm. 878, de 30 de noviembre de 2010, cit., p. 25. 
convenio y deban actualizarse las aportaciones atendiendo a cada caso en particular, sin que por ello se vicie la validez del convenio" 63 .

\section{Contenido del convenio}

El TCu puso de manifiesto la inaplazable necesidad de precisar los extremos que han de comprender los convenios en su contenido ${ }^{64}$. A tal fin, el art. 49 LRJSP establece un pormenorizado guion, que supera con creces el nivel de detalle previsto hasta ahora en el art. 6.2 LRJ-PAC. De acuerdo con aquel, los convenios deberán incluir: i) la identificación de los sujetos que suscriben y la capacidad jurídica con la que interviene cada parte; ii) la competencia en la que se fundamenta la actuación, (sin que el convenio pueda constituir una cesión de la misma ex art. 48.1); iii) el objeto del convenio y las actuaciones que debe realizar cada sujeto, indicando, en su caso, la titularidad de los resultados que se obtengan; iv) la obligaciones y compromisos económicos que asume cada una de las partes, si los hubiera; v) el régimen de modificación del convenio. Con ello, se pretende corregir una serie de problemas habituales en la práctica convencional de la Administración, como la falta de concreción en el objeto de los convenios, la genérica descripción de las actividades a realizar y la falta de precisión en el alcance, adecuación y criterios de las aportaciones efectuadas por las Administración.

La nueva regulación introduce, además, importantes avances en la fase de ejecución de los convenios, apostando por la seguridad jurídica. De un lado, se prevé que los convenios deberán establecer mecanismos de seguimiento, vigilancia y control tanto de la ejecución de los convenios como de los compromisos adquiridos por las partes. La LRJSP atribuye a este mecanismo las facultades necesarias para supervisar la ejecución, adoptar las decisiones y dictar las instrucciones oportunas, con el fin de asegurar la correcta realización de las actividades convenidas ${ }^{65}$. En cuanto a la configuración de este mecanismo, bien como órgano mixto, - en el que participen representantes de cada una de las partes-, bien como un órgano arbitral, será esta una cuestión a decidir por los firmantes del convenio ${ }^{66}$. De otra parte, se

63 Fuertes López, M., "Los convenios y los consorcios ...”, cit., p. 20.

64 Cfr. Dictamen del TCu núm. 878, de 30 de noviembre de 2010, cit., p. 32.

65 Entre las funciones reconocidas a estos mecanismos de seguimiento, vigilancia y control destacan las de interpretación de las dudas que se susciten y acreditación del correcto cumplimiento del convenio (art. 49 LRJSP); o la proponer, en caso de extinción del convenio, la continuación y finalización de las actuaciones en curso que consideren oportunas, estableciendo un plazo improrrogable para su finalización, (art. 52 LRJSP).

${ }_{66}$ Como señala Fuertes López, "queda a discreción de los firmantes perfilar este instrumento que podrá configurarse como un órgano mixto en el que participen representantes, como un órgano arbitral separado, incluso, dependiendo de la trascendencia del objeto del convenio, su remisión a la Cámara legislativa que también controlará la actividad del Gobierno. Podría también la legislación autonómica de 
establece la exigencia legal de prever, en el instrumento de formalización, un régimen de consecuencias ante un posible incumplimiento, en el que se incluyan, en su caso, los criterios para determinar una eventual indemnización por los perjuicios que pudieran derivarse. Esta última previsión, como se verá, adquiere especial relevancia de cara a una posible resolución del convenio por incumplimiento de las obligaciones y compromisos asumidos por parte de alguno de los firmantes.

Junto con lo anterior, la LRJSP aborda otro problema recurrente de la actividad convencional de la Administración: la falta de un concreto plazo de vigencia de los convenios y de un procedimiento expreso para su prórroga. El legislador ha querido reforzar el carácter temporal de esta figura delimitando su duración, aun en contra del criterio de quienes consideran que una mayor longevidad del convenio fortalece la estabilidad del sistema o de quienes entienden que fijar una limitación a su vigencia contraría la naturaleza flexible de los instrumentos de colaboración y la libertad de pacto $^{67}$. De acuerdo con esto, el art. 49 LRJSP incorpora un límite temporal para los convenios, cuya duración no podrá ser superior a cuatro años, salvo que normativamente se prevea un plazo superior ${ }^{68}$.

No obstante, antes de la finalización del convenio, los firmantes podrán acordar, por unanimidad, su prórroga, por un periodo de hasta cuatro años adicionales, o su extinción ${ }^{69}$. Ahora bien, pese a su aparente sencillez, esta última restricción plantea algunas dudas sobre su alcance. Cabe preguntarse si el art. 49 LRJSP limita el número de prórrogas posible o sólo afecta a la duración de estas. Las posturas doctrinales son contrarias. Para García Luengo, no hay duda de que el art. 49.2.h) comprende "una limitación que afecta a la forma en la que se deciden las prórrogas,

desarrollo atribuir esta función a los órganos especializados en la resolución de los recursos de contratación. Varias son las posibilidades". Fuertes López, M., "Los convenios y los consorcios...”, cit., p. 20; con un criterio similar, vid., Colás Tena, J., "Encomiendas de gestión...”, cit., p. 182.

67 En este sentido, son relevantes las enmiendas formuladas por distintos grupos parlamentarios al proyecto de LRJSP. Así, el Grupo Parlamentario Catalán de Convergència i d’Unió propuso la supresión de la limitación de la vigencia de los convenios a cuatro años motivándolo en la necesaria conservación de la naturaleza flexible de los instrumentos de colaboración y la libertad de pactos. En la misma línea, el Grupo Parlamentario de Unión Progreso y Democracia, en sus enmiendas al Proyecto de Ley, puso de manifiesto que "cuanto más longevos sean los convenios aportará mayor estabilidad al sistema". Vid. Enmiendas núms. 12 y 13 y 119 al Proyecto de LRJSP, (BOCG, Congreso de los diputados, X Legislatura, núm. 154-2, de 28 de julio de 2015).

${ }_{68}$ Un ejemplo serían convenios que se subscriban para delegar competencias a las Corporaciones locales han de extenderse al menos durante cinco años, ex art. 27 de la Ley 7/1985, de 2 de abril, reguladora de las Bases del Régimen Local.

69 En este sentido, especifica la Ley que, para el caso de convenios suscritos por la AGE o alguno de sus organismos públicos y entidades de derecho público vinculados o dependientes, esta prórroga deberá ser comunicada al Registro Electrónico estatal de Órganos e Instrumentos de Cooperación al que se refiere la Disposición adicional $7^{\text {a }}$ de la LRJSP. 
- siempre por un máximo de cuatro años-, pero no al número de prórrogas, ya que de otro modo no se podrían celebrar convenios para atender necesidades destinadas a permanecer como el sostenimiento de un museo o de un centro de investigación"70. Por lo tanto, los convenios tendrán una duración de 4 años, (salvo los que normativamente tengan prevista otra duración), pudiendo prorrogarse cuentas veces sean necesarias por periodos nunca superiores a cuatro años. Sin embargo, no son pocos los autores que, frente a este criterio, entienden que el art. 49 LRJSP permite, en realidad, una única prórroga cuya duración se limita a otro periodo máximo de cuatro años ${ }^{71}$. Como explica De Diego Gómez, "se comprueba que no está prevista la posibilidad de una sucesión de prórrogas, sino solamente una, no pudiendo variarse esta circunstancia ni por la voluntad de las partes intervinientes, ni tampoco por ninguna otra norma, al no preverse este extremo como sí se hace en el apartado anterior para la determinación del plazo inicial"72. Por tanto, el hecho de que la concatenación de prórrogas no quede expresamente prevista, ni se brinden excepciones en este sentido, permitiría concluir que, salvo las excepciones legales, los convenios tienen una duración máxima de cuatro años prorrogables solamente una vez más por otro plazo máximo de cuatro años.

Es cierto que, coincidiendo con la primera postura, el Anteproyecto de LRJSP, mantenía en el art. 24 que, "los firmantes del convenio podrán acordar unánimemente su prórroga por un periodo de hasta cuatro años adicionales o su extinción", añadiendo a continuación que, "excepcionalmente, el plazo de vigencia de los convenios y sus prórrogas podrá ser superior a cuatro años sin exceder de cincuenta”. Resulta obvio que la intención del legislador, al menos en ese momento, era limitar la duración de los convenios y de sus prórrogas permitiendo su encadenamiento hasta un máximo de cincuenta años. Pero también lo es que, si la voluntas legislatoris hubiera sido mantener esta opción, bien podría haber conservado la redacción del art. 24 del Anteproyecto, o bien, introducir previsiones expresas en este sentido, tal y como ocurre en el TRLCSP ${ }^{73}$.

La importancia de cuanto se ha expuesto queda patente a la luz de la Disposición adicional $8^{\mathrm{a}}$ que, al margen del plazo de tres años previsto para la adaptación

70 García Luengo, J., "Instituciones sustantivas...”, cit., pp. 14-27.

71 Fuertes López, M., "Los convenios y los consorcios...", cit., p. 24.

72 De Diego Gómez, A., "La figura del convenio tras la Ley 40/2015, del Régimen Jurídico el Sector Público", El consultor de los Ayuntamientos, Wolters Kluwer, núm. 23, 2015, p. 6.

73 A modo de ejemplo, el art. 23 TRLCSP, bajo la rúbrica «Plazo de duración de los contratos» dispone que, "el contrato podrá prever una o varias prórrogas siempre que sus características permanezcan inalterables durante el período de duración de éstas"; en la misma línea, en el art. 26 TRLCSP, «Contenido mínimo del contrato» se alude a "la duración del contrato o las fechas estimadas para el comienzo de su ejecución y para su finalización, así como la de la prórroga o prórrogas, si estuviesen previstas". Por lo tanto, a la vista de las fórmulas empleadas en el TRLCSP, la ausencia de previsiones similares en la LRJSP conduce a pensar que, no es voluntad del legislador permitir más de una prórroga en los convenios. 
de los convenios preexistentes, prevé la aplicación automática de las nuevas reglas sobre vigencia a todos los convenios que no tuvieran un plazo determinado o que, aun teniéndolo, tuvieran establecida una prórroga tácita por tiempo indefinido en el momento de la entrada en vigor de la Ley $^{74}$.

\section{Trámites preceptivos para la suscripción de los convenios}

Con carácter general y sin perjuicio de las especialidades que la legislación autonómica pueda prever, la LRJSP exige, para poder suscribir el convenio, cumplir con los trámites preceptivos señalados en el art. 50. Cualquiera que sea la Administración pública, organismo público y entidad de derecho público vinculada o dependiente, o la Universidad pública que participe en el convenio, la norma exige la presentación de una memoria justificativa en la que se analicen los siguientes extremos: i) su necesidad y oportunidad, es decir, las carencias existentes y las ventajas derivadas del uso del convenio; ii) su impacto económico, a fin de medir la repercusión y los beneficios derivados de la actuación conjunta; y, iii) su adecuación a la legalidad, reflejando el carácter no contractual de la actividad que desarrolla, así como el cumplimiento del resto de previsiones legales que le resulta de aplicación.

Junto con esto, para el caso de los convenios suscritos por la AGE o sus organismos públicos y entidades de derecho público vinculados o dependientes, la LRJSP añade una serie de requisitos específicos como, por ejemplo, contar con un informe de su servicio jurídico ${ }^{75}$; cualquier otro informe preceptivo que establezca la normativa aplicable; la autorización previa del MHAP para su firma, modificación, prórroga y resolución por mutuo acuerdo entre las partes; o la remisión al Senado, por el MHAP, de los convenios interadministrativos suscritos con las CGAA. Además, se prevé que, cuando los convenios plurianuales suscritos entre Administraciones públicas incluyan aportaciones de fondos por parte del Estado para financiar actuaciones a ejecutar exclusivamente por parte de otra Administración pública y el Estado asuma, en el ámbito de sus competencias, los compromisos frente a terceros, la aportación del Estado de anualidades futuras estará condicionada a la existencia de crédito en los correspondientes presupuestos ${ }^{76}$.

$74 \quad$ En estos casos, de acuerdo con la Disposición adicional $8^{\mathrm{a}}$, el plazo de vigencia de los convenios será de cuatro años a contar desde el pasado día 2 de octubre de 2016.

75 No será necesario solicitar el informe de los servicios jurídicos cuando el convenio se ajuste a un modelo normalizado informado previamente por el servicio jurídico que corresponda art. 50.2. a) LRJSP.

76 Para García Luengo, este apartado será objeto de la doctrina del enriquecimiento injusto, en la medida que "revela el afán de la Hacienda estatal de limitar la eficacia de los compromisos adquiridos en los convenios". García Luengo, J., "Instituciones sustantivas ...", cit., pp. 14-27. Asimismo, De Diego GómEz aventura la necesaria intervención de la jurisprudencia ante la falta de coherencia de lo que parece deducirse de este apartado, esto es, "que en un convenio plurianual, los compromisos asumidos por el Estado frente a terceros estarán condicionados a la existencia de crédito en los correspondientes presupuestos 


\section{Extinción de los convenios y sus efectos}

En cuanto a la extinción de los convenios, la LRJSP parte de una premisa básica, los convenios se extinguen, o por la debida satisfacción de su objeto, — de forma que quedan sin razón de ser-, o porque se haya incurrido en alguna causa de resolución. El art. 51 LRJSP incorpora una novedosa relación de posibles causas de resolución por la que se enmienda la acusada insuficiencia normativa de la LRJ-PAC en este extremo. Junto con la extinción del convenio por el transcurso del plazo de vigencia sin haberse acordado su prórroga, —única causa prevista con anterioridad -, la Ley establece ahora, como causas legales para la resolución del convenio, la decisión unánime de todos los firmantes; el incumplimiento de alguna de las partes de las obligaciones y compromisos que fueron asumidos; o el dictado de una resolución judicial que declare la nulidad del convenio. Causas generales a las que deberán sumarse, además, aquellas que específicamente contemple el convenio.

Pese a la claridad del art. 51 LRJSP, algunas de estas causas de resolución precisan un examen más detenido. Así, si bien es lógico que la decisión unánime de todos los firmantes conduzca a la resolución del convenio, contrarius consensus, también lo es que deban tenerse en cuenta los posibles efectos que de dicha resolución pudieran dimanarse para terceros. Como señala Fuertes López, "habrá que analizar si de su contenido no iban a emanar más que expectativas, otras ventajas que beneficiaban a terceros, derechos a favor de los vecinos, que deben ser salvaguardados. (...) En estos casos, en que desentenderse de un convenio perjudica a terceros, deberían reconocerse mecanismos para no agostar esos beneficios esperados y poder exigir su cumplimiento aislado al urbanizador o a la Administración responsable" 77.

Asimismo, la LRJSP incluye, entre las causas de resolución, el incumplimiento de las obligaciones y compromisos asumidos por parte de alguno de los firmantes. Si bien, en aras de evitar posibles conflictos e incluso de facilitar la conservación del convenio, la Ley habilita para este supuesto un procedimiento específico. Se prevé que, sobrevenido el incumplimiento, cualquiera de las partes pueda remitir, al miembro incumplidor, un requerimiento por el que se le exija la debida satisfacción de lo convenido dentro de un plazo determinado. Este requerimiento deberá remitirse

futuros" y el hecho de que, "de un lado, un compromiso de gasto frente a terceros documentado a través de un convenio deba tener su reflejo en los correspondientes presupuestos y no al revés; y de otro, por ser imperativo legal, ex art. 48.5, que los convenios que incluyan compromisos financieros deberán ser financieramente sostenibles, debiendo quienes los suscriban tener capacidad para financiar los asumidos durante la vigencia del convenio". De Diego Gómez, A., "La figura del ...”, cit., p. 7.

77 La autora se refiere aquí a "convenios con particulares, convenios urbanísticos que facilitaran algunas cesiones, compromisos de obras o mejoras a favor de los vecinos; convenios con empresas para ampliar sus prestaciones; convenios interadministrativos a partir de los cuales alguna Administración ampliaba sus proyectos". Fuertes López, M., "Los convenios y los consorcios...”, cit., p. 25. 
tanto al responsable del mecanismo de seguimiento, vigilancia y control de la ejecución del convenio, como a las demás partes firmantes. De acuerdo con la literalidad del precepto, si transcurrido el plazo concedido el incumplimiento persiste, se entenderá resuelto el convenio, previa notificación al resto de firmantes. En este caso, la indemnización de los daños que pudieran derivarse será procedente siempre que así se acordara en el instrumento de formalización del convenio, ex art.49 LRJSP $^{78}$.

En la medida en la que los convenios son negocios jurídicos que nacen de un acuerdo de voluntades, su cumplimiento es obligatorio para todos los sujetos que los suscriben. Por lo tanto, parece lógico que, ante un incumplimiento, se proceda a su resolución, evitando obligar a la parte cumplidora a mantener su fidelidad con los compromisos adquiridos o, en su caso, asumir las consecuencias del incumplimiento. Sin embargo, podría entenderse que, la falta de medidas previas a la ruptura definitiva convierte la resolución del convenio en una respuesta excesivamente rotunda $^{79}$. Ahora bien, la aparente contundencia del art. 51 c) cede a la luz del art. 49 LRJSP. Como se vio, junto con los mecanismos de seguimiento, vigilancia y control, los convenios deben prever, en su instrumento de formalización, las consecuencias aplicables ante un posible incumplimiento y, en su caso, los criterios para determinar la posible indemnización de los daños. Por ello, es posible que los convenios incluyan alguna alternativa previa a la resolución, como la salida de uno de los firmantes en caso de ser varios, - bien del incumplidor, bien de quien lo interese- o un posible régimen sancionador, quedando la resolución por incumplimiento como la última opción ante dicha conducta.

Por último, la extinción del convenio, tanto por cumplimiento como por resolución, dará lugar a la liquidación del mismo con el objeto de determinar las obligaciones y compromisos de cada una de las partes. Esta cuestión adquiere especial relevancia en el caso de la extinción de convenios de los que deriven compromisos financieros. Así pues, con el fin de garantizar la compensación de las partes y evitar el enriquecimiento injusto de cualquiera de ellas, el art. 52 LRJSP establece unas reglas para la liquidación de estos convenios. Si de la liquidación resultara que el importe de las actuaciones ejecutadas por alguna de las partes fuera inferior a los fondos que

78 En este sentido, García Luengo destaca la importancia de que "en la elaboración del convenio se tenga en cuenta la necesidad de fijar dicha indemnización ya que, en otro caso, no surgiría automáticamente el derecho a resarcirse a favor de la parte cumplidora en lo que supone una vulneración de un principio básico del Derecho de obligaciones reflejado en el artículo 1124 CGv". García Luengo, J., "Instituciones sustantivas ...” cit.

79 Fuertes López pone de relieve que, "la preocupación por conflictos vividos, en que la falta de eficaces instrumentos para hacer cumplir las obligaciones derivadas de una firma generaba graves perjuicios, conduzca ahora a la rotunda ruptura del convenio, supone atender a una solución extrema". Fuertes LÓPEZ, M., "Los convenios y los consorcios ...", cit., p. 25. 
hubiera recibido para financiar dicha ejecución, aquella deberá reintegrar al resto de firmantes del convenio el exceso proporcional que a cada uno corresponda. Para ello, la Ley concede el plazo máximo de un mes a partir del cual comenzará el devengo de intereses de demora. Intereses que, de acuerdo con el tenor literal del precepto, deberán ser abonados al resto de partes del convenio en un nuevo plazo de un mes. Desde un punto de vista práctico, la redacción empleada por el legislador en el art. 52.2.a) LRJSP puede plantear dudas de cara al ejercicio de posibles reclamaciones judiciales no quedando claro qué puede reclamarse en qué momento ${ }^{80}$.

Ahora bien, en caso de que se produzca el fenómeno inverso, es decir, que el importe de las actuaciones ejecutadas fuera superior a los fondos recibidos, corresponderá al resto de las partes del convenio abonar a la parte de que se trate la diferencia que proporcionalmente corresponda a cada una de ellas, haciéndolo en el plazo de un mes desde que se apruebe la liquidación y con el límite máximo de las cantidades que cada una de ellas se hubiera comprometido a aportar en virtud del convenio. En ningún caso las partes del convenio tendrán derecho a exigir al resto cuantía alguna que supere los citados límites máximos. Estos límites deben ser puestos en relación con los requisitos de eficacia de los convenios, en concreto, con la previsión del art. 48.6 LRJSP, de acuerdo con el cual, las aportaciones financieras que se comprometan a realizar los firmantes no podrán ser superiores a los gastos derivados de la ejecución del convenio. Por ello, como señala De Diego Gómez, cuando la ejecución del convenio suponga un mayor coste final que el inicialmente previsto, la parte que se encargue de dicha ejecución debe promover primeramente la modificación del convenio antes de aprobar el aumento del gasto, pues de otra forma no podrá reclamarles la diferencia a las otras partes intervinientes, al dejar claro que no tendrá derecho a exigirles cuantía alguna que supere los límites máximos a que cada una se hubiera comprometido"

Finalmente, el art. 52.3 LRJSP aborda otra de las deficiencias apuntadas por el TCu: la insatisfactoria regulación de la forma de finalización, en caso de resolución del convenio, de las actuaciones en curso de ejecución ${ }^{82}$.Dispone el precepto que, en

80 Así, en el art. 52.2.a) LRJSP, se habla de un primer plazo de un mes, desde la liquidación del convenio, para que la parte que ha recibido el exceso de fondos lleve a cabo el reintegro correspondiente al resto de partes. Cumplido ese plazo voluntario sin haberse realizado la devolución, la Ley concede un segundo plazo de un mes, cuyo computo se inicia al finalizar el plazo voluntario, para abonar los intereses devengados por la falta de reintegro. De este modo, no queda claro si, finalizado el plazo de un mes para el reintegro voluntario, pueden ejercitarse acciones judiciales para reclamar el principal y los intereses que se devenguen hasta el efectivo abono; si se puede reclamar el principal, pero hasta pasado el segundo plazo de un mes no los intereses, (que podrán ser abonados durante un mes de forma voluntaria); o si se debe esperar al cumplimiento del segundo plazo de un mes para poder reclamar el total de lo adeudado.

81 De Diego Gómez, A., "La figura del ...", cit., p. 8.

82 Dictamen del TCu núm. 878, de 30 de noviembre de 2010, cit., p. 14. 
caso de darse este supuesto, "las partes, a propuesta de la comisión de seguimiento, vigilancia $y$ control del convenio o, en su defecto, del responsable del mecanismo a que hace referencia la letraf) del art. 49, podrán acordar la continuación y finalización de las actuaciones en curso que consideren oportunas, estableciendo un plazo improrrogable para su finalización, transcurrido el cual deberá realizarse la liquidación de las mismas".

Debe llamarse la atención sobre la diferenciación que se introduce entre «la comisión de seguimiento, vigilancia y control del convenio y el responsable del mecanismo», y que, sin embargo, no tiene correspondencia con el art. 49 f) al que se remite. El citado precepto alude exclusivamente al mecanismo de seguimiento, generándose una incoherencia entre artículos que, ya advertida por el Consejo de Estado en el Anteproyecto de Ley, debió ser corregida ${ }^{83}$.

\section{Remisión de los convenios al Tribunal de Cuentas}

Termina el Capítulo vi del Título preliminar de la LRJSP con los sistemas de control contable ejercidos por el TCu u órgano externo de fiscalización de las CCAA. El art. 53 establece expresamente la obligación de las entidades del sector público de remitir electrónicamente al TGu u órgano externo de fiscalización de la CA (OCEx), según corresponda, aquellos convenios cuyos compromisos económicos asumidos superen los 600.000€, haciéndolo en el plazo de tres meses desde su suscripción, así como la de comunicar las modificaciones, prórrogas o variaciones de plazos, alteración de los importes de los compromisos económicos asumidos y la extinción de los convenios indicados. Junto con lo anterior, dispone el precepto que, las previsiones anteriormente indicadas se entenderán sin perjuicio de las facultades del TCu, o del correspondiente OCEx, para reclamar cuantos datos, documentos y antecedentes estime pertinentes con relación a los convenios de cualquier naturaleza y cuantía ${ }^{84}$.

83 En este sentido, el Consejo de Estado puso de manifiesto que "el artículo 27.3 del Anteproyecto previene que, si existieran actuaciones en curso cuando concurra cualquiera de las causas de resolución del convenio, las partes podrán acordar la continuación o finalización de las mismas «a propuesta de la comisión de seguimiento, vigilancia y control del convenio o, en su defecto, del responsable del mecanismo a que hace referencia la letra f) del artículo 24». Sin embargo, el art. 24.f) no contempla distinción alguna entre comisión de seguimiento, vigilancia y control del convenio y responsable del mecanismo, ni hace referencia a este último, razones por las que se sugiere modificar su redacción”. Vid. Dictamen núm. 274/2015, del Consejo de Estado, de 29 de abril, cit.

${ }_{84}$ En realidad, el art. 53.3 LRJSP se refiere de forma expresa a las facultades del TCu, o del correspondiente órgano de fiscalización externo de la CA, para reclamar "cuantos datos, documentos, y antecedentes estime pertinentes con relación a los contratos de cualquier naturaleza y cuantía". Entendemos que la intención del legislador fue la de referirse a los convenios y no a los contratos, encontrándonos ante un error de redacción. Este descuido, que adquiere especial relevancia en una Ley caracterizada por el esfuerzo de diferenciar ambas figuras, pudiera derivar de una mala adaptación de la recomendación núm. 16 del TCu en su Dictamen núm. 878, de 30 de noviembre de 2010, en la que el Alto Tribunal propone 
La LRJSP cumple de este modo con la recomendación efectuada por el TCu relativa a que la obligación de remitir al Alto Tribunal información sobre los contratos celebrados por entidades del sector público se hiciera extensiva, con las necesarias adaptaciones, a los convenios de colaboración. Para normalizar el cumplimiento de esta obligación, el TGu ha ido concretando la información y documentación relativa a los convenios que se le deben remitir, así como el procedimiento y medio para llevarlo a cabo. Respecto de las entidades del Sector Público estatal y autonómico, deberá tenerse en cuenta la Instrucción general, de 28 de noviembre de 2013, relativa a la remisión telemática al Tribunal de Cuentas de los extractos de los expedientes de contratación y de las relaciones de contratos, convenios y encomiendas de gestión celebrados por las entidades el Sector Público Estatal y Autonómico ${ }^{85}$; y, respecto a las entidades del sector público local, la Instrucción, de 24 de noviembre de 2016, relativa a la remisión telemática al Tribunal de Cuentas de convenios y de relaciones anuales de los celebrados por las entidades del Sector Público local ${ }^{86}$.

De esta manera, se facilita el ejercicio de fiscalización en la materia ya que, al disponerse de información sobre el conjunto de los convenios celebrados en cada ejercicio, resulta posible una adecuada planificación y ejecución del control en esta área de la gestión.

\section{BREVE RECAPITULACIÓN FINAL}

Se cierra el presente estudio con la recapitulación de algunas de las consideraciones efectuadas.

Primera.- La reforma emprendida por la LRJSP responde, en gran medida, a la necesidad de adoptar soluciones tendentes a superar los efectos de la crisis económica. El objetivo es alcanzar una mejora en la eficacia de la actuación administrativa que se traduzca, a la postre, en un más atento cumplimiento de los principios de

"que la obligación de remitir al TCu información sobre los contratos celebrados por las entidades del sector público que se regula en el art. 29 LCSP y en los arts. 39 y 40 LFTCu, se haga extensiva con las necesarias adaptaciones a los convenios de colaboración”. Dictamen del TCu núm. 878, de 30 de noviembre de 2010, cit., p. 34 .

${ }^{85}$ Resolución de 10 de diciembre de 2013, de la Presidencia del Tribunal de Cuentas, por la que se publica el Acuerdo del Pleno de 28 de noviembre de 2013, sobre la instrucción general relativa a la remisión telemática al Tribunal de Cuentas de los extractos de los expedientes de contratación y de las relaciones de contratos, convenios y encomiendas de gestión celebrados por las entidades del Sector Público Estatal y Autonómico, (BOE núm. 301, de 17 de diciembre de 2013).

86 Resolución de 2 de diciembre de 2016, de la Presidencia del Tribunal de Cuentas, por las que se publica el Acuerdo del Pleno de 24 de noviembre de 2016, por el que se aprueba la Instrucción relativa a la remisión telemática al Tribunal de Cuentas de convenios y de relaciones anuales de los celebrados por las entidades del Sector Público local, (BOE núm. 295, de 7 de diciembre de 2016). 
disciplina presupuestaria y estabilidad financiera. Este propósito rige el nuevo marco legal de los convenios con el que se pretende mejorar la fiscalización del gasto público que se realiza a través de esta figura. En este sentido, el Capítulo vi, del Título preliminar de la LRJSP establece un marco jurídico sustantivo y de procedimiento de los convenios, - - tanto los que se suscriben entre Administraciones o entidades públicas como los que se suscriben con administrados-, en el que se integran las recomendaciones realizadas por el TCu en su Dictamen núm. 878, de 30 de noviembre de 2010.

Segunda.- La LRJSP introduce un concepto legal de convenio, superando las dificultades derivadas del uso de un concepto residual de esta figura. Con esta definición, la mayor concreción de sus ámbitos subjetivo y objetivo y una incipiente diferenciación de figuras análogas, se pretende evitar que, bajo el nomen iuris convenio, se siga dado cobijo a realidades jurídicas tan heterogéneas. Junto con lo anterior, se añade una nueva clasificación en la que deberán hallar correspondencia todos los convenios vigentes. La Ley deja atrás la tradicional distinción entre convenios de colaboración y de cooperación para referirse, ahora, a convenios interadministrativos, intradministrativos, los firmados con sujetos de Derecho privado y los no constitutivos ni de Tratado internacional, ni de Acuerdo internacional administrativo, ni de Acuerdo internacional no normativo.

Tercera.- Se condiciona la validez y eficacia de los convenios al cumplimiento de unos requisitos concretos. Junto con la imposibilidad de alterar la distribución constitucional de competencias, las Administraciones deberán ampliar la información disponible de los convenios, manteniendo actualizados los correspondientes registros electrónico de los órganos de cooperación en los que participen y de convenios que se hayan suscrito. En el caso de los convenios en los que forme parte la AGE, la inscripción del convenio en el referido registro y su publicación en el BOE se tornan requisitos esenciales para su eficacia. Asimismo, los convenios deberán cumplir con los principios de estabilidad presupuestaria y sostenibilidad financiera. La LRJSP se remite a la legislación presupuestaria para el desarrollo de actuaciones relacionadas con los gastos derivados de los convenios que incluyan compromisos financieros. Y lucha contra los abusos en el gasto público a través de medidas como la prohibición expresa de que las aportaciones financieras que se comprometan a realizar los firmantes sean superiores a los gastos derivados de la ejecución del convenio.

Cuarta.- Se establece un pormenorizado guion de los extremos que se han de comprender en el contenido de los convenios. La Ley avanza en la necesaria concreción del objeto y las actividades a realizar por cada sujeto que conviene y, en su caso, la titularidad de los resultados. Se incluye como obligatorio el régimen de modificación del convenio y las consecuencias aplicables en caso de incumplimiento de las obligaciones y compromisos asumidos por cada una de las partes, pudiendo in- 
cluirse en su caso, los criterios para determinar una posible indemnización. La nueva regulación introduce, además, importantes progresos en la fase de ejecución de los convenios apostando por la seguridad jurídica. Los convenios deberán establecer mecanismos de seguimiento, vigilancia y control, tanto de la ejecución de los convenios, como de los compromisos adquiridos por las partes. Atribuyéndose a este mecanismo las facultades necesarias para supervisar la ejecución y adoptar las decisiones y dictar las instrucciones oportunas con el fin de asegurar la correcta realización de las actividades convenidas.

Quinta.- El legislador ha querido reforzar el carácter temporal de los convenios poniendo fin a la falta de un concreto plazo de vigencia y de un procedimiento expreso para su prórroga. Se limita su duración a un máximo de cuatro años, salvo que normativamente se prevea un plazo superior y queda prevista la posibilidad de que los firmantes acuerden por unanimidad, antes de su finalización, una prórroga del convenio por un periodo de hasta cuatro años adicionales, o su extinción. La importancia de las nuevas reglas sobre la vigencia de los convenios queda patente en su aplicación automática. Esta afectará a todos los convenios que no tuvieran un plazo determinado o que, teniéndolo, hayan incluido una prórroga tácita por tiempo indefinido en el momento de la entrada en vigor de la Ley.

Sexta.- En cuanto a la extinción de los convenios, la LRJSP parte de una premisa básica, los convenios se extinguen, o por la debida satisfacción de su objeto, - de forma que quedan sin razón de ser-, o porque se haya incurrido en alguna causa de resolución. La norma incorpora una novedosa relación de posibles causas legales de resolución a la que deberán sumarse las previstas por el propio convenio. Se corrige de este modo la acusada insuficiencia normativa de la LRJ-PAC en este extremo. Se regulan, además, los efectos de la extinción, esto es, la liquidación de los convenios. Una cuestión que adquiere especial relevancia en el caso de convenios de los que deriven compromisos financieros. En este sentido, son básicas las reglas fijadas en aras de garantizar la compensación de las partes, evitando el enriquecimiento injusto de cualquiera de ellas. Ante la posible resolución de los convenios, se hace necesario establecer la forma de terminación de las actuaciones en curso de ejecución. En estos casos, la Ley prevé que las partes, a propuesta del mecanismo de seguimiento del convenio, podrán acordar la continuación y finalización de las actuaciones en curso que consideren oportunas, estableciendo un plazo improrrogable para su finalización transcurrido el cual deberá realizarse la liquidación de las mismas.

Séptima.- Por último, puede hablarse de un incremento de la transparencia en la gestión de los fondos públicos a través del control externo de la actividad convencional del sector público con contenido económico. Se establece la obligación de las entidades del sector público de remitir electrónicamente al TCu u órgano externo de fiscalización 
de la CA (OCEx), según corresponda, aquellos convenios cuyos compromisos económicos asumidos superen el umbral de los 600.000€, asi como la de comunicar las modificaciones, prórrogas o variaciones de plazos, alteración de los importes de los compromisos económicos asumidos y la extinción de los convenios indicados. Todo ello, sin perjuicio de las facultades del TGu o del correspondiente OCEx para reclamar cuantos datos, documentos, y antecedentes estime pertinentes con relación a los convenios de cualquier naturaleza y cuantía.

De este modo, la Ley 40/2015, de 1 de octubre, de Régimen Jurídico del Sector Público ha elevado a rango de ley las propuestas y recomendaciones del TCu y del Informe CORA, arrojando luz en la práctica administrativa. Aun cuando han quedado pendientes algunas cuestiones importantes, — como la recomendación del TCu de que, ante la gran variedad de convenios existentes y sus diferentes exigencias, cada Administración o Departamento ministerial pudiera elaborar una normativa reguladora propia, dentro del marco legal general-, el nuevo régimen jurídico de los convenios ha sido valorado de forma positiva, debiendo adaptarse al mismo todos los convenios preexistentes no más tarde del 2 de octubre de 2019. 


\section{BIBLIOGRAFÍA}

Colás Tena, J., "Encomiendas de gestión, encargos y convenios en la Ley 40/2015, de 1 de octubre, de Régimen jurídico del Sector Público", Cuadernos de Derecho Local, núm. 41, 2016.

Comisión para la Reforma de las Administraciones Públicas (CORA), Informe de la Reforma de las Administraciones Públicas, Gobierno de España, Madrid, 2013.

De Diego Gómez, A., "La figura del convenio tras la Ley 40/2015, del Régimen Jurídico el Sector Público", El consultor de los Ayuntamientos, Wolters Kluwer, núm. 23, 2015.

Fuertes López, M., "Los convenios y los consorcios en la Ley del Sector Público", conferencia impartida en el Seminari de Dret Local: les lleis 39 i 40 de 2015, de Procediment Administratiu i Règim Furídic del Sector Públic, Federación de Municipios de Cataluña, Barcelona, 20 de noviembre de 2015.

García Luengo, J., "Instituciones sustantivas en la Ley 40/2015, de Régimen Jurídico del Sector Público: los principios de la potestad sancionadora, la responsabilidad administrativa y el nuevo régimen de los convenios administrativos", El Cronista del Estado Social y Democrático de Derecho, núm. 63, 2016.

Gimeno Feliu, J.M., "El efecto directo de las Directivas de contratación pública de 2014 en ausencia de transposición en plazo en España", Contratación administrativa práctica: revista de la contratación administrativa y de los contratistas, núm. 143, 2016.

Mellado Ruiz, L., "Ámbito subjetivo y objetivo de la aplicación de la Ley de Contratos del Sector Público", RAAP, núm. 74, 2009.

Menéndez Rexach, A., "Encomiendas de gestión y convenios", Cuadernos de Derecho Local, núm. 41, 2016.

Muñoz-Charles Coyle, M.L., "La nueva regulación de los convenios entre Administraciones públicas y particulares”, Actualidad Jurídica Aranzadi núm. 914, 2015.

Organización para la Cooperación y el Desarrollo Económico (OCDE), España: de la reforma administrativa a la mejora continua. Resumen ejecutivo, hallazgos y recomendaciones clave, Estudios de Gobernanza Pública de la OCDE, 2014.

Pascual García, J., "La regulación de los convenios administrativos en la Ley de Régimen Jurídico del Sector Público", Revista Española de Control Externo, vol. XviII, núm. 54, 2016. 
- Convenios de colaboración entre Administraciones públicas y convenios con administrados, BOE, Madrid, 2012.

Rodríguez de Santiago, J.M., Los Convenios entre Administraciones Públicas, Marcial Pons, Ediciones Jurídicas y Sociales, S.A., Madrid, 1997.

Santiago Iglesias, D., "Las relaciones de colaboración entre poderes adjudicadores excluidas de la normativa de contratación del sector público una propuesta de transposición de la regulación contenida en las Directivas de contratación al ordenamiento español", Revista General de Derecho Administrativo, núm. 38, 2015.

— "Los convenios interadministrativos", en Yzquierdo Tolsada, M. (Dir.), Tratado de Contratos, tomo XIV, Aranzadi, Cizur Menor, 2014.

Tribunales Administrativos de Contratación Pública, Los efectos jurídicos de las Directivas de contratación pública ante el vencimiento del plazo de transposición sin nueva Ley de contratos públicos, OBCP, Madrid, 2016. 